\title{
UNFRIENDLY PERSUASION: ENJOINING RESIDENTIAL PICKETING
}

\author{
HAZEL A. LANDWEHR
}

\begin{abstract}
Imagine that one pleasant Sunday afternoon, you look out your window and see a group of twenty to fifty people picketing on the street in front of your home. The picketers are carrying signs that name you. Although the gathering is "peaceful," the very presence of the crowd is threatening, prompting you to close your windows, draw your blinds, and keep your family in the house until the picketers leave.

Now imagine that these same picketers, in greater or lesser numbers, re-create this same event at your home every Sunday afternoon. What should be a day of rest spent with your family becomes an ordeal. Your children cannot play in the yard by themselves or in the streets with their friends. Any strange car parked across the street or driving slowly past the house feeds your anxiety. On Saturday night, anticipating the events to come on Sunday, you and your family become nervous and agitated. Because friends must traverse a gauntlet to reach your home, they stop coming to visit. Your home has become a fortress under siege; the only difference is that you and your family are not the fortress's defenders but its captives.
\end{abstract}

\section{INTRODUCTION}

This hypothetical situation is much like the one that Dr. Eduardo Aquino and his family faced in March 1988. A group of anti-abortion activists began to picket on the residential street in front of the Aquinos' home in suburban Corpus Christi, Texas. ${ }^{1}$ The picketers returned for four separate vigils that month, each lasting approximately an hour and a half. Although not silent, the picketers were peaceful and did not shout at the house, threaten

1. Response of Respondents to Application of Petitioners for Writ of Error at 5 , Valenzuela v. Aquino, 853 S.W.2d 512 (Tex. 1993) (No. D-0740). The same activists had picketed Dr. Aquino "at his office and at a clinic where he practices." Id. 
its occupants, or trespass on the Aquinos' property. ${ }^{2}$ Nevertheless, the incidents were traumatic for the family. ${ }^{3}$

The Aquinos sought and were granted a temporary injunction that barred the named defendants from protesting within one-half mile of the Aquinos' home. ${ }^{4}$ The Texas Court of Appeals held this prohibition overbroad, dissolved the injunction, ${ }^{5}$ and remanded the case for a trial on the merits. ${ }^{6}$ The jury returned a verdict in favor of the Aquinos and awarded them compensatory and punitive damages for negligent infliction of emotional distress. The trial court entered judgment against the defendants for the amount of the jury's verdict and granted a permanent injunction requiring the defendants "to desist and refrain from engaging in any type of picketing within 400 [feet] of the center of the lot upon which Plaintiffs' home is located."

The defendants appealed the decision. The appellate court reversed the award of damages ${ }^{9}$ but upheld the injunction as a reasonable accommodation between the defendants' First Amendment rights and the plaintiffs' right to residential privacy. ${ }^{10}$ Rely-

2. Id.

3. Id. at 5-6 (noting that the doctor's wife "suffered a virtual nervous breakdown," and that "[o]ne child, Freddie, became reclusive, was institutionalized, and eventually had to leave the country") (citations omitted).

4. See Valenzuela v. Aquino, 763 S.W.2d 43, 44 (Tex. Ct. App. 1988) (setting forth the terms of the temporary injunction granted below).

5. Id. at 46.

6. Response of Respondents to Application of Petitioners for Writ of Error at 6, Valenzuela v. Aquino, 853 S.W.2d 512 (Tex. 1993) (No. D-0740).

7. Id.

8. Id. (citation omitted).

9. The jury awarded total damages of $\$ 810,000$ to the Aquinos- $\$ 310,000$ in actual damages and $\$ 500,000$ in punitive damages. Valenzuela v. Aquino, 800 S.W.2d 301, 307 (Tex. Ct. App. 1990), rev'd in part, 853 S.W.2d 512 (Tex. 1993). The appellate court found that these awards violated both the Federal and Texas Constitutions and reversed this part of the trial court's judgment. Id. at 309.

It is beyond the scope of this Note to address the issues that the award and reversal of damages in Valenzuela raise. It is interesting to note, however, that defendants in subsequent cases have argued against residential picketing injunctions by alluding to the fact that plaintiffs have an adequate remedy at law, namely, damages. See DefendantsAppellants' Brief at 12, Kaplan v. Prolife Action League, 431 S.E.2d 828 (N.C. Ct. App. 1993), appeal docketed, No. $92185 C 459$ (N.C. Aug. 20, 1993). Clearly, if the right to residential privacy is to have any substantive ineaning, one of these theories cannot be correct.

10. Valenzuela, 800 S.W.2d at 306 . The court also rejected the defendants' argument that the injunction violated the Equal Protection Clause because it affected only the named defendants and therefore only the ideas they wished to express. See id. (relying on Pickens v. Okolona Mun. Separate Sch. Dist., 594 F.2d 433, 438 (5th Cir. 1979)). 
ing on the U.S. Supreme Court's analysis in Frisby v. Schultz, ${ }^{11}$ the court held that the injunction was a reasonable time, place, and manner restriction on the defendants' First Amendment rights. ${ }^{12}$

More than two years after granting a writ of error in the case, the Supreme Court of Texas decided that the Aquinos had not sufficiently proven an actionable tort to support the injunction. ${ }^{13}$ It therefore dissolved the injunction and remanded the case for a new trial. ${ }^{14}$ The court refused to consider the constitutional issues on the ground that they were "hypothetical."15

The question of how best to balance free speech rights and residential privacy interests is the focus of this Note. When the U.S. Supreme Court decided Frisby in 1988, it believed that it had struck that balance in a way that gave adequate protection to both interests-freeing residents from the evils of picketing targeted at their homes while allowing protestors ample freedom to exercise their First Amendment rights. Subsequent history has proven the Court wrong. Finding the spirit of Frisby, if not the exact letter, easily evaded, protestors have continued to invade residents' privacy by merely extending the length of their picket lines. Ultimately, the balance struck in Frisby was no balance at all; homeowners have been forced to seek injunctive relief from the courts. $^{16}$

In deciding to remand without resolving the constitutional issues, the Texas Supreme Court failed to resolve two important

11. 487 U.S. 474 (1988).

12. Valenzuela, 800 S.W.2d at 304-06.

13. Valenzuela v. Aquino, 853 S.W.2d 512, 513 (Tex. 1993).

14. Id. at 514.

15. Id. Several dissenting judges would have decided the constitutional questions in favor of the Aquinos. See id. at 514-19 (Gonzales, J., dissenting); id. at 520-25 (Spector, J., dissenting).

16. See Northeast Women's Ctr., Inc. v. McMonagle, 745 F. Supp. 1082 (E.D. Pa.), modified, 749 F. Supp. 695 (E.D. Pa. 1990), affd, 939 F.2d 57 (3d Cir. 1991); Boffard v. Barnes, 591 A.2d 699 (N.J. Super. Cl. Ch. Div. 1991); Kaplan v. Prolife Action League, 431 S.E.2d 828 (N.C. Cl. App. 1993), appeal docketed, No. $9218 S C 459$ (N.C. Aug. 20, 1993); Dayton Women's Health Ctr. v. Enix, 589 N.E.2d 121 (Ohio Ct. App. 1991), cert. denied, 112 S. Ct. 3033 (1992); Klebanoff v. McMonagle, 552 A.2d 677 (Pa. Super. Ct. 1988); cf. Ramsey v. Edgepark, Inc., 583 N.E.2d 443, 451 (Ohio Cl. App. 1990) ("Based upon this court's reading of Frisby, any impingement beyond this narrow regulation of time, place and manaer would be an infringement upon the First Amendment rights of those attempting to use the public streets to communicate their message to the community."). 
questions that the defendants in Valenzuela advanced in their appeal: first, that injunctions are categorically prior restraints on speech and are therefore unconstitutional; ${ }^{17}$ and second, that even if some restrictions on free speech are permissible, Frisby defines the outermost limits of those restrictions that are consistent with First Amendment principles. ${ }^{18}$

This Note argues against both propositions. The right to residential privacy is a significant one that government may legitimately protect. Moreover, there is a judicially cognizable difference between a legitimate attempt to participate in the "marketplace of ideas" and an attempt to physically and psychologically intimidate someone into acquiescence with one's own beliefs under the guise of exercising free speech rights. The First Amendment does not constrain courts from recognizing this distinction and granting specific, narrowly tailored injunctions barring individuals from exercising their free speech rights in a particular way that has been proven to harm the targeted resident's privacy interests. Several courts in the post-Frisby era have explicitly or implicitly acknowledged the validity of this argument in fashioning injunctions that create a picket-free area within a certain radius of the targeted resident's home. ${ }^{19}$ Such injunctions are consistent with the requirements of the time, place, and manner doctrine, which defines the ambit of permissible regulations on speech.

Part I discusses the central building blocks of this thesis: the First Amendment doctrines of prior restraint and time, place, and manner, the residential privacy right, and the U. S. Supreme Court's decision in Frisby v. Schultz. Given these general legal principles, Part II demonstrates that residential picketing injunctions fail to satisfy the traditional definitions of prior restraint. Part III argues that when residential picketing injunctions are examined under a broader definition of "focused picketing" that accounts for picketers' intent, such injunctions can be viable time, place, and manner regulations. Finally, from this expanded notion of focused picketing, Part IV articulates a test, based on whether picketers

17. Petitioners' Application for Writ of Error at 26-29, Valenzuela v. Aquino, 853 S.W.2d 512 (Tex. 1993) (No. D-0740).

18. See id. at $30-31$.

19. See Northeast Women's Ctr., 745 F. Supp. at 1090; Boffard, 591 A.2d at 700; Kaplan, 431 S.E.2d at 831; Dayton Women's Health Ctr., 589 N.E.2d at 127; Klebanoff, 552 A.2d at $678-81$. 
have had a "fair opportunity" to communicate their message, for determining when an injunction is appropriate to protect residential privacy.

It is important to note that anti-abortion groups are only the most recent in a long line of protestors who have taken their cause to the residential streets in front of the homes of private individuals whose views or practices they oppose. Labor protestors, ${ }^{20}$ civil rights demonstrators, ${ }^{21}$ and gay rights activists ${ }^{22}$ have all found residential picketing a profoundly potent weapon in the arsenal of social change. The arguments advanced here are meant to apply with equal force to residential picketing on any subject of social or political discourse. No matter what message protestors seek to convey through use of the picket line, it does not justify the repeated invasion of residential privacy.

\section{RIGHTS IN THE BALANCE: GENERAL PRINCIPLES}

\section{A. The First Amendment Doctrines}

Although the text of the First Amendment proclaims, "Congress shall make no law ... abridging the freedom of speech,"23 it is virtually undisputed that free speech rights are not absolute and may be regulated in the interest of other important government goals in appropriate circumstances. ${ }^{24}$ The issues, therefore, are under what circumstances government may infringe on free speech rights and for what purposes. The prior restraint and time, place, and manner doctrines address these questions.

1. Prior Restraint. In the realm of First Amendment doctrine, prior restraints are the most odious and least tolerable restrictions on speech. ${ }^{25} \mathrm{~A}$ prior restraint is a regulation that gives

20. See, e.g., K-T Marine, Inc. v. Dockbuilders Local Union 1456, 597 A.2d 563 (N.J. Super. Ct. Ch. Div. 1990), affd, 597 A.2d 540 (N.J. Super. Ct. App. Div. 1991).

21. See, e.g., Gregory v. City of Chicago, 394 U.S. 111, 125-26 (1969) (Black, J., concurring).

22. See, e.g., Walinsky v. Kennedy, 404 N.Y.S.2d 491 (Sup. Ct. 1977).

23. U.S. ConsT. amend. I (emphasis added).

24. Konigsberg v. State Bar of Cal., 366 U.S. 36, 49-51 (1961). See generally JoHN E. NOWAK \& RONALD D. ROTUNDA, CONSTTTUTIONAL LAW $\S 16.7(\mathrm{~b}$ ), at $942-44$ (4th ed. 1991).

25. Bantam Books, Inc. v. Sullivan, 372 U.S. 58, 70 (1963) ("[A] system of prior restraints of expression comes to this Court bearing a heavy presumption against its constitutional validity."). 
public officials the power to deny a potential speaker access to a particular forum before that speaker has uttered a word. If "the purpose of the First Amendment [is] to preserve an uninhibited marketplace of ideas in which truth will ultimately prevail,"26 such censorship is intolerable; it stymies the search for truth by siphoning off certain thoughts and opinions before they have had a reasonable opportunity to be tested in the marketplace.

Despite its uniform condemnation of prior restraints, the U.S. Supreme Court has not clarified a consistent set of criteria for determining when a prior restraint exists. ${ }^{27}$ This incoherence is particularly troublesome given that once the Court has labeled a regulation a prior restraint, it is virtually certain to find the regulation unconstitutional. ${ }^{28}$ Here, however, only two relatively unproblematic observations about prior restraints are necessary.

The first is that prior restraints invoke strict scrutiny. ${ }^{29} \mathrm{Al}-$ though this standard is difficult to satisfy, ${ }^{30}$ not all regulations that have some impact on free speech rights are subject to strict

26. Red Lion Broadcasting Co. v. FCC, 395 U.S. 367, 390 (1969). The "marketplace of ideas" terminology originated with Justice Holmes, who said, "The best test of truth is the power of [a] thought to get itself accepted in the competition of the market." Abrams v. United States, 250 U.S. 616, 630 (1919) (Holmes, J., dissenting).

27. The Court has attached the prior restraint label to activities that both bear little resemblance to true censorship and have little in common with each other. See Marin Scordato, Distinction Without a Difference: A Reappraisal of the Doctrine of Prior Restraint, 68 N.C. L. REV. 1, 6-7 (1989). Professor Scordato notes that "prior restraint" has been used to describe everything from an injunction, $i d$. at 6 (citing, inter alia, Oklahoma Publishing Co. v. District Court, 430 U.S. 308, 311-12 (1977) (per curiam)), to a tax on the cost of paper and ink, id. at 7 (citing Minneapolis Star \& Tribune Co. v. Minnesota Comm'r of Revenue, 460 U.S. 575, 592-93 (1983)), to a city's refusal to allow a touring production of the musical Hair to appear at its municipal theater, id. at 7 (citing Southeastern Promotions, Ltd. v. Conrad, 420 U.S. 546, 564 (1975)).

28. Theoretically, the presumption against prior restraints can be overcome only in very limited circumstances: publication of wartime deployments, obscenity, and "incitements to acts of violence and the overthrow by force of orderly government." Near v. Minnesota, 283 U.S. 697, 716 (1931). In practice, however, the exceptions have not been so limited. See Scordato, supra note 27 , at 7.

29. See Bantam Books, 372 U.S. at 70 (noting that prior restraints "bear[] a heavy presumption against [their] constitutional validity"). Strict scrutiny requires that the regulation bear a necessary relation to a compelling government interest. See Planned Parenthood of S.E. Pa. v. Casey, 112 S. Ct. 2791, 2847 (1992) (citing Griswold v. Connecticut, 381 U.S. 479, 485 (1965)); see also NoWAK \& ROTUNDA, supra note 24, § 14.3, at 575.

30. See LAURENCE H. TRIBE, AMERICAN CONSTITUTIONAL LAW \$12-2, at 791-92 (2d ed. 1988) (noting limited exceptions under which restrictions on fundamental rights may be permissible); cf. Korematsu v. United States, 323 U.S. 214, 219-20 (1944) (holding that the government could use its war power to justify the internment of Japanese-American citizens during World War II). 
scrutiny. The Court has upheld regulations of disruptive or harmful conduct, even if that conduct is intended to communicate a message, as long as the regulation is not principally designed to silence the message itself. ${ }^{31}$

The second is that courts historically have classified injunctions as prior restraints. In the seminal case of Near v. Minneso$t a{ }^{32}$ the Supreme Court simultaneously incorporated the prior restraint doctrine into modern jurisprudence and characterized injunctions as typical of regulations forbidden under the doctrine. In Near, the Court considered an injunction issued pursuant to a nuisance abatement statute that allowed the state to enjoin publication of any "malicious, scandalous and defamatory newspaper, magazine or other periodical." ${ }^{33}$ Under the statute, the defendant was prosecuted for publishing a series of highly inflammatory, antiSemitic articles that accused the local government of conspiring with organized crime. ${ }^{34}$ The trial court permanently enjoined further publication of the newspaper. ${ }^{35}$

The U.S. Supreme Court reversed on the ground that the statute in effect made the issuing court a review board through which the defendant would have to clear every subsequent publication to avoid the possibility of being held in contempt. ${ }^{36}$ "This," said the Court, "is the essence of censorship." 37 Characterizing the history of the First Amendinent as part of an "effort[] to secure freedom from oppressive adininistration,"38 the Court affirmed " $[t]$ he general principle that the constitutional guaranty of the liberty of the press gives immunity from previous restraints." 39

Since Near, the Court has struck down injunctions as prior restraints several times. ${ }^{40}$ In recognizing these precedents, how-

31. See infra notes 108-14 and accompanying text.

32. 283 U.S. 697 (1931).

33. Id. at 702 (quoting MNN. STAT. § 10123-1(b) (Mason 1927)).

34. Id. at 724 n.1 (Butler, J., dissenting).

35. Id. at 705 .

36. Id. at $712-13$.

37. Id. at 713 .

38. Id. at 717 (footnote oinitted).

39. Id. at 719.

40. See Nebraska Press Ass'n v. Stuart, 427 U.S. 539, 569 (1976) (striking a pre-trial gag order enjoining publication of information about a murder on the grounds that the plaintiff had "not demonstrated with the degree of certainty our cases on prior restraint require" that pre-trial publicity would adversely affect his right to a fair trial); New York 
ever, one should note several important differences between the injunctions that the Court has struck down and the type of injunctions issued in Valenzuela and the other residential picketing cases. First, and most important, unlike the injunction in Near, which was "not aimed at the redress of individual or private wrongs" and could issue "upon the mere proof of publication," 41 residential picketing injunctions specifically redress individual wrongs and require substantial proof of actual harm. ${ }^{42}$ Second, the majority of the Court's prior restraint cases have involved attempts to censor the press based on the content of the proposed publication. Such content-based restrictions on "pure speech" are quite different from injunctions banning "expressive conduct"-such as picketing-regardless of its message. ${ }^{43}$ Lastly, the appellate court in Valenzuela issued an injunction only after a full hearing on the merits. ${ }^{44}$ This injunction therefore did not suffer from the procedural problems that the Court has found central in other cases. ${ }^{45}$

Times Co. v. United States, 403 U.S. 713, 714 (1971) (per curiam) (finding that the U.S. government had failed to sustain the "heavy burden" of proving that a prior restraint was warranted to enjoin The New York Times and The Washington Post from publishing a classified study about government decisionmaking in Vietnam) (quoting Organization for a Better Austin v. Keefe, 402 U.S. 415, 419 (1971)); see also Pittsburgh Press Co. v. Human Relations Comm'n, 413 U.S. 376, 396 (1973) (Burger, C.J., dissenting) ("[E]very member of the [New York Times] Court, tacitly or explicitly, accepted the . . . condemnation of prior restraint as presumptively unconstitutional."). But see United States v. The Progressive, Inc. 467 F. Supp. 990, 1000 (W.D. Wis. 1979) (enjoining publication of an article describing how to manufacture a hydrogen bomb on the grounds that the government's proof established a likelihood of "direct, immediate and irreparable injury").

Although the Court did characterize the picketing injunction in Carroll v. President of Princess Anne, 393 U.S. 175 (1968), as a prior restraint, its decision to strike the injunction was based chiefly on the lower court's failure to provide appropriate procedural protections. Id. at 181. In failing to solicit the petitioners' input, the lower court could not have undertaken a "balanced analysis" of the issues required in the delicate area of First Amendment rights. Id. at 183.

41. Near, 283 U.S. at 709; see also Keefe, 402 U.S. at 418 ("Here, as in [Near], the injunction operates, not to redress alleged private wrongs, but to suppress, on the basis of previous publications, distribution of literature 'of any kind' in a city of 18,000.").

42. See infra subsection II(A)(1).

43. See infra subsection II(B)(1).

44. Valenzuela v. Aquino, 800 S.W.2d 301, 303 (Tex. Ct. App. 1990), rev'd in part, 853 S.W.2d 512 (Tex. 1993).

45. See Carroll v. President of Princess Anne, 393 U.S. 175, 184 (1968); see also Nebraska Press Ass'n v. Stuart, 427 U.S. 539, 542 (1976) (noting that "no attorney for [the] members of the press appeared" to contest the issuance of the gag order); Howard Gault Co. v. Texas Rural Legal Aid, Inc., 615 F. Supp. 916, 935-36 (N.D. Tex. 1985) (relying on the fact that temporary restraining order was issued ex parte in determining that the order violated protestors' First Amendment rights), rev'd in part, 848 F.2d 544 
2. Time, Place, and Manner Restrictions. If a regulation is not a prior restraint, it still must meet the requirements of the time, place, and manner doctrine. Under that doctrine, a restriction must satisfy four requirements: ${ }^{46}$

(1) the restriction must be content-neutral. It must apply to all messages equally; ${ }^{47}$

(2) the restriction must be narrowly tailored. A regulation satisfies this requirement if the chosen means are "not substantially broader than necessary to achieve the government's interest;" 48

(3) the restriction must serve a significant government interest. Some important interest must be at stake to justify the infringement of First Amendment rights;

(4) the restriction must leave open ample alternative channels of communication. The speaker must have available other avenues to disseminate her message. ${ }^{49}$

The time, place, and manner doctrine is an attempt to balance the rights of free speech with other important goals that government may legitimately advance. It is based on a recognition that "the First Amendment does not guarantee the right to communicate one's views at all times and places or in any manner that may be desired." ${ }^{50}$ The government may, in certain contexts, infringe on free speech rights to protect other compelling interests. ${ }^{51}$ Within the home, privacy is such an interest.

(5th Cir. 1988). (1983).

46. See, e.g., Perry Educ. Ass'n v. Perry Local Educators' Ass'n, 460 U.S. 37, 45

47. See, e.g., City of Renton v. Playtime Theatres, 475 U.S. 41, 47 (1986); Carey v. Brown, 447 U.S. 455, 460-63 (1980); Police Dep't of Chicago v. Mosley, 408 U.S. 92, 96 (1972).

48. Ward v. Rock Against Racism, 491 U.S. 781, 800 (1989).

49. However, the mere fact that the speaker could go elsewhere is not dispositive of the ample alternatives element: "[O]ne is not to have the exercise of his liberty of expression in appropriate places abridged on the plea that it may be excrcised in some other place." Schneider v. State, 308 U.S. 147, 163 (1939).

50. See Heffron v. International Soc'y for Krishna Consciousness, 452 U.S. 640, 647 (1981); see also Schenck v. United States, 249 U.S. 47, 52 (1919) ("[T]he character of every act depends upon the circumstances in which it is done.").

51. See Buckley v. Valeo, 424 U.S. 1, 66 (1976) (per curiam) ("We have acknowledged that there are governmental interests sufficiently important to outweigh the possibility of imfringement [of First Amendment rights] . . . ."). 


\section{B. The Right to Privacy}

As previously noted, freedom of speech is important in a democratic society because free exchange in the marketplace of ideas enhances the search for truth. ${ }^{52}$ Yet, if the realm of speech and thought is indeed a marketplace, the modern marketplace is vastly different from any that has come before. In our increasingly global society, in which a cacophony of competing messages, opinions, and ideas vie for our allegiance, the few remaining opportunities for escape-for privacy-become all the more important. ${ }^{53}$ The right to residential privacy implicates a right to a degree of tranquility and well-being within one's home and within one's community. ${ }^{54}$ The state can protect this right through its police power. ${ }^{55}$

In recognizing a right to residential privacy, the Court has drawn an important distinction between the home and the marketplace. When people venture out in the world, they are likely to come in contact with any number of messages and ideas. They may agree with some and be offended by others, but in no case do they have a right to censor a message simply because they disagree with it. Theoretically, in the marketplace of ideas, all ideas must be heard before an individual can ascertain the truth of any. ${ }^{56}$ To avoid messages she does not want to consider, she carries the burden of walking away or averting her eyes. ${ }^{57}$

The home, by contrast, is "the sacred retreat to which families repair for their privacy and their daily way of living, ... the last citadel of the tired, the weary, and the sick." ${ }^{38}$ Within this en-

52. Red Lion Broadcasting Co. v. FCC, 395 U.S. 367, 390 (1969); see supra note 26 and accompanying text.

53. See Samuel D. Warren \& Louis D. Brandeis, The Right of Privacy, 4 HARV. L. REV. 193, 196 (1890) ("The intensity and complexity of life, attendant upon advancing civilization, have rendered necessary some retreat from the world, and man, under the refining influences of culture, has become more sensitive to publicity, so that solitude and privacy have becoine more essential to the individual.").

54. See Kovacs v. Cooper, 336 U.S. 77, 83 (1949).

55. Id.; see also Carolson v. California, 310 U.S. 106, 113 (1940) (noting that the Court has recognized the "power and duty of the State to take adequate steps to preserve the peace and protect the privacy, the lives, and the property of its residents").

56. See New York Times Co. v. Sullivan, 376 U.S. 254, 270 (1964) (stating that the purpose of First Amendment is to preserve "uninhibited, robust, and wide-open" debate).

57. Erznoznik v. City of Jacksonville, 422 U.S. 205, 212 (1975); Cohen v. California, 403 U.S. 15, 21 (1971).

58. Gregory v. City of Chicago, 394 U.S. 111, 125 (1969) (Black, J., concurring). 
clave, no one is required to listen to any message she does not want to hear, regardless of how important that idea might be in the larger search for truth. ${ }^{59}$ This ability to control the flow of ideas into the home is based not only on a concern for preserving the sanctity of the home but also on a recognition that homeowners present a captive audience for speakers. Within the home, there is not the same opportunity to walk away from unwanted communication that exists in the marketplace. More importantly, homeowners are not required to walk away; the state may protect their residential privacy interests by restricting unwanted forms of communication directed at the home. ${ }^{60}$

Solicitous of the concerns of the unwilling listener, the U.S. Supreme Court has found a variety of intrusions to be invasive of residential privacy. ${ }^{61}$ These precedents, which clearly establish a right to privacy within the home, as well as the ascendancy of that right over the First Amendment rights of others seeking to communicate with residents, served as the basis for the Court's decision in Frisby v. Schultz.

59. See Rowan v. United States Post Office Dep't, 397 U.S. 728, 736 (1970) (stating that although restrictions on free speech "ha[vel the effect of impeding the flow of ideas, information, and arguments that, ideally, [the homeownerl should receive and consider," they are permissible).

This proposition is true even if the communication is otherwise meritorious and deserving of consideration. See id. at 738 ("[N]o one has a right to press even 'good' ideas on an unwilling recipient."); id. at 737 ("Nothing in the Constitution compels us to listen to or view any unwanted communication, whatever its merit ...."); Kovacs, 336 U.S. at 86 (insisting that the Court has "never intimated that the visitor could insert a foot in the door and insist on a hearing").

60. See Consolidated Edison Co. v. Public Serv. Comm'n, 447 U.S. 530, 541 (1980) ("[T]he ability of government 'to shut off discourse solely to protect others from hearing it [is] dependent upon a showing that substantial privacy interests are being invaded in an essentially intolerable manner."') (quoting Cohen, 403 U.S. at 21)).

61. See, e.g., FCC v. Pacifica Found., 438 U.S. 726, 748 (1978) (holding that radio broadcast of offensive comedy monologue could be sanctioned because "in the privacy of the home, ... the individual's right to be left alone plainly outweighs the First Amendment rights of an intruder"); Rowan, 397 U.S. at 737 (holding that a resident has the right to request that her naine be removed from a mailing list and that all future mailings cease; " $[\mathrm{t}] \mathrm{he}$ ancient concept that 'a man's home is his castle' into which 'not even the king may enter' has lost none of its vitality") (citing Camara v. Municipal Court, 387 U.S. 523 (1967)); Kovacs, 336 U.S. at 89 (upholding a Trenton, New Jersey ordinance banning sound trucks from broadcasting "loud and raucous" noises in residential neighborhoods on the ground that "the need for reasonable protection in the homes ... . justifies the ordinance"). 
C. Frisby v. Schultz

The Supreme Court's decision in Frisby v. Schultz, ${ }^{62}$ especially its strong articulation of the residential privacy right, ${ }^{63}$ was central to the appellate court's decision in Valenzuela v. Aquino, ${ }^{64}$ as well as to the decisions of other courts that have considered residential picketing injunctions since Frisby. ${ }^{65}$ The outcome in Frisby, however, was extremely limited and, in fact, has permitted picketers to continue to infringe on the residential privacy rights that the Frisby Court sought to protect. ${ }^{66}$

In Frisby, a group of abortion protestors challenged a Brookfield, Wisconsin ordinance that banned picketing "before or about the residence or dwelling of any individual." The plaintiffs had been and wished to continue picketing the home of a local gynecologist who performed abortions as part of his practice. The picketers sought injunctive and declaratory relief, claiming that the ordinance violated their First Amendment rights. ${ }^{67}$ In reviewing their claims, the Court analyzed the ordinance under the time, place, and manner doctrine. ${ }^{68}$

Building on prior decisions that allowed the state to take an interest in protecting the sanctity of the home and the captive and

62. 487 U.S. 474 (1988).

63. See infra notes 69-74 and accompanying text.

64. 800 S.W.2d 301, 305 (Tex. Ct. App. 1990), rev'd in part, 853 S.W.2d 512 (Tex. 1993).

65. See, e.g., Northeast Women's Ctr., Inc. v. McMonagle, 745 F. Supp. 1082 (E.D. Pa.), modified, 749 F. Supp. 695 (E.D. Pa. 1990), affd, 939 F.2d 57 (3d Cir. 1991); Boffard v. Barnes, 591 A.2d 699 (N.J. Super. Ct. Ch. Div. 1991); Kaplan v. Prolife Action League, 431 S.E.2d 828 (N.C. Ct. App. 1993), appeal docketed, No. $9218 S C 459$ (N.C. Aug. 20, 1993); Dayton Women's Health Ctr. v. Enix, 589 N.E.2d 121 (Ohio Ct. App. 1991); Klebanoff v. McMonagle, 552 A.2d 677 (Pa. Super. Ct. 1988).

66. It is beyond the scope of this Note to offer more than the highlights of the Frisby opinion. For more thorough analyses of the opinion itself, see Robert E. Rigby, Jr., Comment, Balancing Free Speech in a Public Fortunt vs. Residential Privacy: Frisby v. Schultz, 24 NEw ENG. L. REv. 889 (1990); Carolyn D. Cowan, Note, Frisby v. Schultz: Where Do the Picketers Go Now? "We'll Just Have to Wait and See," GEO. MASON U. L. REV., Summer 1989, at 227; Randall M. England, Note, Residential Picketing: Balancing Freedom of Expression and the Right to Privacy, 54 Mo. L. REV. 209 (1989); Todd R. Seelman, Note, The Illusion of Residential Privacy: The Doctrine of Time, Place, and Manner Regulation Revisited, Frisby v. Schultz, 12 HAMLINE L. REV. 447 (1989); E. Gregory Wallace, Note, 11 U. ARK. LITTLE Rock L.J. 691 (1989); Note, The Supreme Court, 1987 Term-Leading Cases, 102 HARV. L. REV. 143, 261-271 (1988) [hereinafter Leading Cases].

67. Frisby v. Schultz, 487 U.S. $474,476-77$ (1988).

68. Id. at $481-88$. 
unwilling listener, ${ }^{69}$ the Court found the right to residential privacy to be a government interest "of the highest order in a free and civilized society." Although courts have long recognized that picketing is antithetical to residential privacy, ${ }^{71}$ Frisby took this analysis one step further: it found residential picketing to be inherently offensive to residential privacy. ${ }^{72}$ Because "the 'evil' of targeted residential picketing, 'the very presence of an unwelcome visitor at the home,' [was] 'created by the medium of expression itself," "73 Brookfield could enact a complete ban on residential picketing to promote its significant interest in residential privacy. ${ }^{74}$

Despite this strong language supporting the right to residential privacy, the Court still had to ensure that the ordinance was narrowly tailored to "target[] and eliminate[] no more than the exact source of the 'evil' it [sought] to remedy."75 That evil, according to the Court, was "focused picketing."76 It was this type of picketimg that the Court presumed was intended to invade residential privacy. On the other hand, the Court asserted that the ordinance could not be read to prohibit "[g]eneral marching through residential neighborhoods, or even walking a route in front of an entire

69. Id. at 484-85; see supra notes 58-60 and accompanying text.

70. Id. at 484 (quoting Carey v. Brown, 447 U.S. 455, 471 (1980) (Rehnquist, J., dissenting)).

71. For example, in an early labor picketing case, a state appellate court held that picketing could be enjoined on the ground that

[t] he allowable area of economic conflict should not be extended to an invasion of the privacy of the home. Here dwell husband and wife, parents and children, who should enjoy immunity froin the external strife of industrial dispute . . . . ... Picketing homes ... would not aid in establishing the proper environment of a home.

Pipe Machinery Co. v. De More, 76 N.E.2d 725, 727 (Ohio Ct. App. 1947), appeal dismissed, 79 N.E.2d 910 (1948).

72. Frisby, 487 U.S. at 486 ("To those inside . . the home becomes something less than a home when and while the picketing ... continue[s] .... [The] tensions and pressures may be psychological, ... but they are not, for that reason, less inimical to family privacy and truly domestic tranquility.") (quoting Carey, 447 U.S. at 478 (Rehnquist, J., dissenting) (quoting City of Wauwatosa v. King, 182 N.W.2d 530, 537 (Wis. 1971))); id. at 487 ("The offensive and disturbing nature of the form of the communication banned ... can scarcely be questioned."); see Leading Cases, supra note 66, at 266.

73. Frisby, 487 U.S. at 487 (quoting Carey, 447 U.S. at 478 (Rehnquist, J., dissenting); City Council v. Taxpayers for Vincent, 466 U.S. 789, 810 (1984)).

74. Id. at $485-88$.

75. Id. at 485 (citing Vincent, 466 U.S. at $808-10$ ).

76. Id. at 483 . 
block of houses"77 but did not more specifically define its terms. So construed, the ordinance was narrowly tailored and preserved ample alternative channels of communication. ${ }^{78}$

The practical limitation of the Court's distinction between focused picketing and general marching is readily apparent in the facts of Valenzuela $v$. Aquino: it has allowed picketers to continue to invade residential privacy in the same inherently offensive way by simply extending the length of their picket line and claiming that they are engaged in a general march rather than a focused picket. $^{79}$ Taken at face value, the distinction between general marching and focused picketing fails to recognize that picketers can still target a particular home without standing directly in front of it. ${ }^{80}$

Frisby, then, has done little to protect the right of privacy that it so strongly affirmed. In fact, Frisby can be construed more broadly to ban protests that extend beyond the frontage of a single home because its definition of focused picketing was based on intent, not mere spatial considerations. ${ }^{81}$ First, however, one must confront another argument raised in Valenzuela that Frisby did not address, namely, whether residential picketing injunctions are unconstitutional prior restraints on expression. ${ }^{82}$

\section{PRior Restraints AND Residential Picketing INJUNCTIONS: A PRINCIPLED DISTINCTION}

In the years since the U.S. Supreme Court's landmark decision in Near $v$. Minnesota ${ }^{83}$ incorporated prior restraint doctrine into twentieth century American jurisprudence and brought injunc-

77. Id.

78. Id. at $483-84$.

79. See Defendants-Appellants' Brief at 8, Kaplan v. Prolife Action League, 431 S.E.2d 828 (N.C. Ct. App. 1993), appeal docketed, No. $9218 S C 459$ (N.C. Aug. 20, 1993); Petitioners' Application for Writ of Error at 30, Valenzuela v. Aquino, 853 S.W.2d 512 (Tex. 1993) (No. D-0740); see also Leading Cases, supra note 66, at 268; Wallace, supra note 66 , at $713-14$.

80. See Leading Cases, supra note 66 , at 270 (suggesting that lower courts should expand the definition of focused picketing to include instances in which "picketers select a particular home as a target for influence or intimidation").

81. See infra Section III(A).

82. See Petitioners' Application for Writ of Error at 26-29, Valenzuela v. Aquino, 853 S.W.2d 512 (Tex. 1993) (No. D-0740).

83. 283 U.S. 697 (1931). 
tions within the ambit of the doctrine, ${ }^{84}$ commentators have generally agreed that injunctions as a category do not belong within that group of regulations subject to such a heavy presumption of invalidity. ${ }^{85}$ The premise of this Part is much more limited: courts can make a principled distinction between residential picketing injunctions-issued after the defendants have had at least one opportunity to communicate their message to the resident and then only on proof of actual harm ${ }^{86}$-and other types of injunctions that in fact do stop speech before it ever occurs based only on a speculation of harm. ${ }^{87}$ This distinction can be maintained under two different definitions of prior restraints: as distinguishable from subsequent punishments and as content-based restrictions on speech.

\section{A. Prior Restraints as Distinct from Subsequent Punishments}

In his Commentaries, Blackstone offered the most influential and frequently quoted definition of prior restraint.

84. See supra notes $32-39$ and accompanying text.

85. Some argue from history, see, e.g., Jeffrey A. Smith, Prior Restraint: Original Intentions and Modern Interpretations, 28 WM. \& MARY L. REV. 439, 462 (1987) ("If the purpose of the first amendment was to prohibit government actions against the press, the Near decision rewrote the Constitution."); others focus on the stage at which the injunction is granted and the procedural safeguards afforded at each stage, see, e.g., Martin H. Redish, The Proper Role of the Prior Restraint Doctrine in First Amendment Theory, 70 VA. L. REV. 53, 83 (1984) ("A proper construction of the prior restraint doctrine, then, would focus exclusively on the issue of providing a full and fair judicial hearing prior to any abridgment."); others take the opposite approach and argue that the focus of the doctrine on the form of injunction diverts attention from the substantive issue of what is being enjoined. See, e.g., John C. Jeffries, Jr., Rethinking Prior Restraint, 92 YALE L.J. 409, 434 (1983) (suggesting that the "doctrine of prior restraint should be retired" because it "has been superseded by the expanded substantive coverage of the First Amendment"); Scordato, supra note 27 , at $28,30-31$ (proposing a literal definition of prior restraint to give the doctrine substantive content).

86. Because an injunction is an extraordinary remedy, a court may not issue one when the claimed harm sought to be enjoined is merely speculative. 11 CHARLES A. Wright \& ARThur R. Miller, Federal Practice \& Proceddure \& 2948, at 370 (1973).

87. E.g., New York Times Co. v. United States, 403 U.S. 713, 714 (1971) (per curiam) (holding that the government had failed to meet its burden in establishing that publication of an article revealing the contents of a study entitled "History of U.S. DecisionMaking Process on Viet Nam Policy" presented a threat to national security interests); $c f$. United States v. The Progressive, Inc., 467 F. Supp. 990, 1000 (W.D. Wis. 1979) (enjoining publication of an article describing how to manufacture a hydrogen bomb based on proof of irreparable hann). 
The liberty of the press is indeed essential to the nature of a free state: but this consists in laying no previous restraints upon publications, and not in freedom from censure from criminal matter when published. Every freeman has an undoubted right to lay what sentiments he pleases before the public: to forbid this, is to destroy the freedom of the press: but if he publishes what is improper, mischievous, or illegal, he must take the consequence of his own temerity. ${ }^{88}$

Relying on this formulation of prior restraint, the U.S. Supreme Court has made much of the distinction between prior restraints and subsequent punishments. ${ }^{89}$ One way in which injunctions against residential picketing might be defined as prior restraints, therefore, is if they are distinguishable from subsequent punishment schemes.

1. The Speculation of Harm. In the Supreme Court's precedents, a significant objection to prior restraints has been that they are often based on poorly substantiated predictions of future harms. ${ }^{90}$ Unsupported fears are insufficient to overcome the strong presumption in favor of free speech. The defendants in Valenzuela v. Aquino ${ }^{91}$ argued on appeal that the injunction against them was a prior restraint because it curtailed future picketing on the mere speculation that actionable harm would occur. ${ }^{92}$

88. 4 William Blackstone, COMMENTARIES $* 151-52$.

89. The Court has said that although "a threat of criminal or civil sanctions after publication 'chills' speech, prior restraint 'freezes' it." Nebraska Press Ass'n v. Stuart, 427 U.S. 539, 559 (1976); see also Carroll v. President of Princess Anne, 393 U.S. 175, 180-81 (1968) ("Ordmarily, the State's constitutionally permissible interests are adequately served by criminal penalties imposed after freedom to speak has been so grossly abused that its immunity is breached. The impact and consequences of subsequent punishment for such abuse are materially different from those of prior restraint.").

Just last Term, the Supreme Court reiterated the importance of the distinction between prior restraints and subsequent punishments. See Alexander v. United States, 113 S. Ct. $2766,2770-73$ (1993). In Alexander, the defendant, a purveyor of pornographic materials, challenged a RICO forfeiture order entered against him as a prior restraint on speech. Id. at 2770 . The Court held that the order did not constitute a prior restraint and that "[t]o accept petitioner's argument would virtually obliterate the distinction, solidly grounded in our cases, between prior restraints and subsequent punishments." Id. at 2771.

90. Nebraska Press, 427 U.S. at 569; New York Tines, 403 U.S. at 730 (Stewart, J., concurring); see also NowaK \& RoTUNDA, supra note 24, § 16.16, at 973 (noting that prior restraimts are predicated on the "predict[ion of] an unknowable future").

91. 800 S.W.2d 301 (Tex. Ct. App. 1990), rev'd in part, 853 S.W.2d 512 (Tex. 1993).

92. Petitioners' Application for Writ of Error at 27-28, Valenzuela v. Aquino, 853 S.W.2d 512 (Tex. 1993) (No. D-0740). 
This argument defies both the facts of the case and common sense. The defendants asked the court to treat each individual episode of picketing as a discrete instance of speech with no connection to past episodes and no predictive value for future ones. If no one knows what the content of those future speech acts will be, the defendants contended, then restrictions barring those future speech acts before they occur are prior restraints. The First Amendment, however, does not require courts to ignore the common-sense conclusion that picketers who have targeted a particular residence in the past are likely to continue to do so in the future. ${ }^{93}$

Moreover, unlike prior restraints, residential picketing injunctions are based not on the fear that harm might occur but on the fact that it already has. ${ }^{94} \mathrm{~A}$ court can issue a permanent injunc-

93. As Justice Stevens has said,

It is entirely proper, however, to draw a distinction between injunctive relief imposing time, place, and manner restrictions upon a class of persons who have persistently and repeatedly engaged in unlawful conduct, on the one hand, and an injunction that constitutes a naked prior restraint against a proposed march by a group that did not have a similar history ....

Hirsh v. City of Atlanta, 495 U.S. 927, 927 (1990) (Stevens, J., concurring) (citation omitted); see also Pittsburgh Press Co. v. Pittsburgh Comm'n on Human Relations, 413 U.S. 376, 390 (1972) (noting that the Court "has never held that all injunctions are impermissible"); Milk Wagon Drivers Union, Local 753 v. Meadowmoor Dairies, 312 U.S. 287, 294-95 (1940) ("Nor can we say that it was written into the Fourteenth Amendment that a state through its courts cannot base protection against future coercion on an inference of the continuing threat of past misconduct.").

This problem may be particularly acute in the abortion protest cases. The conviction with which abortion protest groups hold their beliefs makes it unlikely that they will abandon picketing until their demands are met, i.e. until the doctor stops performing abortions. See Northeast Women's Ctr., Inc. v. McMonagle, 745 F. Supp. 1082, 1092 (E.D. Pa.), modified, 749 F. Supp. 695 (E.D. Pa. 1990), affd, 939 F.2d 57 (3d Cir. 1991).

94. In fact, in order to grant a permanent injunction, a court must first detcrmine that the plaintiff has proven a substantive lort, such as invasion of privacy or private nuisance. See Amoco Prod. Co. v. Village of Gambell, 480 U.S. 531, 546 n.12 (1987) (noting that plaintiff must show "actual success" on the merits of her case to be granted a permanent injunction); Northeast Women's Cir., 745 F. Supp. at 1085 (same); see also Pillsburgh Press, 413 U.S. at 390 ("Because the [injunctive] order is based on a continuous course of repetitive conduct, this is not a case in which the Court is asked to speculate as to the effect ...."); Response of Respondents to Application of Petitioners for Writ of Error at 5-6, Valenzuela v. Aquino, 853 S.W.2d 512 (Tex. 1993) (No. D-0740) (recounling harms visited on the Aquino fanily). Alexander $v$. United States illustrates this point well, despite the Court's characterization of permanent injunctions as classical prior restraints. Alexander v. United States, 113 S. Ct. 2766, 2771 (1993). In drawing the distinction between prior restraints and subsequent punishments, the Court acknowledged that the "constitutional infirmity" of prior restraint lies in the fact that no judicial determination of a constitutional or statutory violation has occurred. Id. at 2771-72. The 
tion only to a plaintiff who succeeds on the merits, which in turn requires the plaintiff to have proved a harm to her protectible interests. $^{95}$ Although residential picketing injunctions restrain some forms of future speech, they do so only on the basis of a demonstrated propensity to abuse that form of speech in a way that harms others. ${ }^{96}$ In this way, residential picketing injunctions act as subsequent punishments for demonstrated First Amendment abuses rather than as prior restraints.

2. Vagueness and Overbreadth Objections. Even if residential picketing injunctions are subsequent punishments rather than prior restraints, they are not automatically constitutionally permissible. If they are overbroad, ${ }^{97}$ restricting more speech than is necessary to prevent the demonstrated harm, or vague, insufficiently specific to allow defendants to know what the injunction prohibits, they are unconstitutional.

Properly formulated residential picketing injunctions, however, suffer from neither of these infirmities. They are not impermissibly vague. They prohibit only one very specific form of speech-picketing. No legal intervention is necessary to identify the standard by which the injunction is broken ${ }^{98}$ reasonable peo-

defendant, by contrast, "had a full criminal trial on the merits," $i d$. at 2772; therefore, his "proposed definition of the term 'prior restraint' would undermine the time-honored distinction between barring speech in the future and penalizing past speech." Id. at 2773.

95. See WrIGHr \& MILLER, supra note $86, \S 2942$, at 370.

96. As noted previously, see supra note 9, the Valenzuela court determined that damages were not available in these circumstances. Valenzuela v. Aquino, 800 S.W.2d 301, 309 (Tex. Ct. App. 1990), rev'd in part, 853 S.W.2d 512 (Tex. 1993). An injunction is therefore the only remedy available to redress these harms.

97. Even if injunctions are not overbroad, however, they still must be narrowly tailored. See infra Section III(B) (discussing how residential picketing injunctions can satisfy the narrow tailoring requirement).

98. For comparison's sake, consider injunctions barring the distribution of obscene materials. In these cases, the court typically makes an initial determination that certain materials the distributor has already sold are obscene. It then issues an injunction barring the distributor from selling these particular materials as well as any other obscene materials. There are two problems with such orders: first, the court has not identified the prohibited materials that the distributor is not to sell in the future; and second, the distributor herself cannot authoritatively identify them prior to their dissemination. Left to guess at what a court might consider to be obscene, the distributor's tendency is to err on the side of self-censorship. See, e.g., FW/PBS, Inc. v. City of Dallas, 493 U.S. 215, 229 (1990); Vance v. Universal Amusement Co., 445 U.S. 308, 316 (1980).

Such "standards injunctions" are both impermissibly vague and overbroad. They have a tendency to chill speech that, if allowed to enter the marketplace, courts would protect under the First Amendment. The difficulty in enjoining the future distribution of 
ple can understand what the injunction prohibits. ${ }^{99}$ Nor are residential picketing injunctions overbroad. ${ }^{100}$ They prohibit only one type of expressive conduct-picketing - that may be regulated in a way that is consistent with the First Amendment. ${ }^{101}$ They are restricted to a discrete and relatively small location. ${ }^{102}$ They do not prohibit other types of speech-for example, leafletting, door-todoor solicitation, telephone canvassing, newsletters and mailers-that have not been shown to cause harm. ${ }^{103}$ Nor do they prohibit picketing itself in other locations-at the targeted resident's place of business, at the public entranceway to her neighborhood, even within other parts of the neighborhood it-

obscene material lies in the fact tbat obscenity is a legal standard; no distributor can know what materials are obscene until a court determines that they are obscene. See Miller v. California, 413 U.S. 15, 24 (1973) (setting out the legal standard for determining whether a particular work is legally obscene). The injunction, therefore, is impermissibly vague because it forces distributors to guess what may or may not be prohibited under the mjunction, and, in the absence of a prior judicial determination, the distributor will be more apt to err on the side of suppression. See Steven T. Catlett, Note, Enjoining Obscenity as a Public Nuisance and the Prior Restraint Doctrine, 84 COLUM. L. REV. 1616, 1626-28 (1984).

99. See Connally v. General Constr. Co., 269 U.S. 385, 391 (1926) (noting that the test of vagueness is whether conduct forbidden by statute is so undefined that persons "of common intelligence must necessarily guess at its meaning and differ as to its application").

100. See Zwickler v. Koota, 389 U.S. 241, 250 (1967) (noting that a statute is void for overbreadth if "it offends the constitutional principle that 'a governmental purpose to control or prevent activities constitutionally subject to state regulation may not be achieved by means which sweep unnecessarily broadly and thereby invade the area of protected freedoms' ") (quoting NAACP v. Alabama, 377 U.S. 288, 307 (1964)).

101. See infra Seetion II(B).

102. See Valenzuela v. Aquino, 800 S.W.2d 301, 306 (Tex. Cl. App. 1990) (noting that injunction barring defendants from picketing within 400 feet of doctor's home had a "specific and limited scope [and] allow[ed] ample alternative avenues of expression"), rev'd in part, 853 S.W.2d 512 (Tex. 1993); cf. Northeast Women's Ctr., Inc. v. McMonagle, 939 F.2d 57, 66-67 (3d Cir. 1991) (modifying lower court residential picketing injunction barring protestors from picketing within 2500 feet of doctors' homes because it was overbroad); Valenzuela v. Aquino, 763 S.W.2d 43, 45 (Tex. Ct. App. 1988) (dissolving as overbroad a temporary mjunction that barred picketers from protesting within one-half inile of the targeted doctor's home).

103. See Response of Respondents to Application of Petitioners for Writ of Error at 9, 11, Valenzuela v. Aquino, 853 S.W.2d 512 (Tex. 1993) (No. D-0740). Frisby itself recognized the validity of this argument.

Protestors have not been barred from the residential neighborhoods. They may enter such neighborhoods, alone or in groups, cven marching .... They may go door-to-door to proselytize their vicws. They may distribute literature in this inanner ... or through the mails. They may contact residents by telephone, short of harassment.

Frisby v. Schultz, 487 U.S. 474, 484 (1988) (citation omitted). 
self-as long as the picketing is not physically focused on the resident's home. For these reasons, residential picketing injunctions are appropriate restrictions on First Amendment rights and are consistent with residents' rights to privacy within their homes.

\section{B. Prior Restraints as Content-Based Restrictions on Speech}

One criticism of the prior restraint/subsequent punishment dichotomy is that its temporal focus does not identify what is truly objectionable about prior restraints, i.e., what characteristics mark them and make them so inimical to a society that values free speech. Not all regulations that arguably might act to chill speech prior to its expression create prior restraints. Interestingly, the Frisby picketers did not argue that the challenged ordinance was a prior restraint on speech, nor did the Court analyze the ordinance under the doctrine, even though the ordinance banned all expression prior to its occurrence. Something more than the temporal aspect of the challenged regulation must be part of the analysis.

One appellate court, faced with the argument that a residential picketing injunction was a prior restraint on speech, characterized a prior restraint as "a content-based restriction on speech prior to its occurrence." 104 Regulations that meet these conditions should be subject to strict scrutiny. ${ }^{105}$ If, however, the challenged regulation applies equally to all messages (thereby evidencing no content-based hostility) and restricts only the conduct elements of the activity (as opposed to the speech elements), a "heavy presumption against its constitutional validity"106 is inappropriate. ${ }^{107}$ Looking at the problem another way, constitutionally permissible time, place, and manner restrictions assume that the conduct in question is regulable and require that the restriction be content-neutral. If the conduct is not regulable, or if the restric-

104. Northeast Women's Ctr., 939 F.2d at 63 (emphasis added).

105. See supra notes $29-31$ and accompanying text.

106. Bantam Books, Inc. v. Sullivan, 372 U.S. 58, 70 (1963).

107. See Scordato, supra note 27 , at 15 ("[T]here is no reason formally to disfavor effective deterrents agaimst speech deemed constitutionally unprotected by the courts."). According to Professor Jeffries,

Where the speech in question is in all events guaranteed by the First Amendment, attributing that guarantee to the circumstance of prior restraint is at best irrelevant and often misleading. The testing case is, rather, one in which speech is concededly ... outside the substantive protection of the First Amendment but assertedly within the ban of prior restraint.

Jeffries, supra note 85 , at 411 . 
tion is based on hostility toward the message, the regulation cannot be a valid time, place, and manner restriction; it must be a prior restraint.

This definition suggests two separate inquiries. The first is whether residential picketing injunctions are content-based, i.e., whether they are premised on no more than the plaintiffs' and the courts' disagreement with the content of the defendants' messages. The second is whether residential picketing injunctions, in regulating the conduct elements of picketing, impermissibly infringe on its speech elements.

1. Determining Whether Speech Is Protected: Pure Speech $v$. Expressive Conduct. The Supreme Court has long recognized that certain acts can communicate messages as well as, or indeed sometimes better than, words alone, ${ }^{108}$ that "in many cases, the medium may well be the message."109 However, such "symbolic speech" or "expressive conduct," involving elements of both speech and conduct, is qualitatively different from "pure speech"-such as publishing a newspaper-because the conduct element has the potential to create "substantial disorder or inva[de] . . . the rights of others." 110

Recognizing these dangers, the Court has approved regulations that incidentally affect the speech component of expressive conduct when a significant government interest is at stake. ${ }^{111}$ In reviewing

108. See, e.g., Texas v. Johnson, 491 U.S. 397 (1989) (burning of American flag at 1984 Republican National Convention); Tinker v. Des Moines Sch. Dist., 393 U.S. 503 (1969) (wearing of black arm-bands in opposition to the Vietnam War).

109. FCC v. Pacifica Found., 438 U.S. 726, 774 (1978) (Brennan, J., dissenting).

110. Tinker, 393 U.S. at 513; see also Blackwell v. Issaquena County Bd. of Educ., 363 F.2d 749, 753-54 (5th Cir. 1966); Boffard v. Barnes, 591 A.2d 699, 701 (N.J. Super. Ct. Ch. Div. 1991) (alluding to the "disruptive potential inherent in the conduct" of residential picketing).

However, the Court has noted that some symbolic acts are so close to pure speech-and with so little potential for disruption or danger-that they should be protected as fully as pure speech. See, e.g., Johnson, 491 U.S. at 408-10 (flag burning); Tinker, 393 U.S. at 505-06 (wearing black arm-bands to school to protest American participation in the Vietnam War). But cf. United States v. O'Brien 391 U.S. 367, 382 (1968) (burning of draft card to protest Vietnam War regulable because government has sufficient interest in orderly administration of draft system to justify a regulation that "is an appropriately narrow means of protecting this interest and condemns only the independent noncommunicative impact of conduct within its reach").

111. FW/PBS, Inc. v. City of Dallas, 493 U.S. 215, 244 (1990) (White, J., concurring in part and dissenting in part) ("The Court has often lield that when speech and nonspeech elements 'are combined in the same course of conduct, a sufficiently important govern- 
such regulations, the Court has drawn a distinction between the form of the speech, which may be regulable, and its content, which is not. ${ }^{112}$ Moreover, the conduct element of expressive conduct is subject to reasonable regulation even if such regulations incidentally infringe on the expression element. ${ }^{113}$ In addition, such regulations must be content-neutral, serve a substantial government interest, and infringe on First Amendment rights no more than is necessary to further that government interest. ${ }^{114}$

Picketing is just such a hybrid of speech and conduct. ${ }^{115} \mathrm{Un}$ doubtedly, picketers have a message that they wish to communicate. The picket line, especially when focused on the home, is a particularly powerful way of communicating that message and has a unique ability to induce action. ${ }^{116}$ However, because picketing entails the amassing of a crowd, it also carries a significant potential for harm; today's peaceable and orderly crowd could become tomorrow's angry and violent mob. ${ }^{117}$ The very presence of the picket line connotes hostility, ${ }^{118}$ even when the picket itself is

mental interest in regulating the nonspeech element can justify incidental limitations on First Amendment freedoms.'”) (quoting O'Brien, 391 U.S. at 376).

112. Justice Stevens formulated this distinction as follows:

[A] counmunication unay be offensive in two different ways. Independently of the message the speaker intends to convey, the form of his communication may be offensive-perhaps because it is too loud or too ugly in a particular setting. Other speeches ... are offensive simply because the listener disagrees with the speaker's message. The fact that the offensive form of some communication may subject it to appropriate regulation surely does not support the conclusion that the offensive character of an idea can justify an attempt to censor its expression.

Consolidated Edison Co. v. Public Serv. Comm'n, 447 U.S. 530. $546-48$ (1980) (Stevens, J., concurring) (footnotes ounitted); see also Police Dep't of Chicago v. Mosley, 408 U.S. 92, 96 (1972).

113. See, e.g., Buckley v. Valeo, 424 U.S. 1, 16 (1976) (per curiam) (quoting O'Brien, 391 U.S. at 376-77).

114. O'Brien, 391 U.S. at 377 . This is, incidentally, the saine criteria applicable to time, place, and manner regulations. See supra subsection $I(A)(2)$.

115. In fact, the pure speech/expressive conduct distinction arose in the Court's early labor picketing cases. See TRIBE, supra note 30, $12-7$, at 825-26.

116. See Note, Picketing the Homes of Public Officials, 34 U. CHI. L. REV. 106, 126 (1966).

117. See Terminiello v. Chicago, 337 U.S. 1, 33 (1949) (Jackson, J., dissenting) ("The crowd mind is never tolerant of any idea which does not conform to its herd opinion. It does not want a tolerant effort at meeting of minds. It does not know the futility of trying to mob an idea."); People v. Levner, 30 N.Y.S.2d 487, 493 (Magis. Ct. 1941) ("Crowds are frowned upon ... because they tend to terrify the average person . . . .).

118. See Frisby v. Schultz, 487 U.S. 474, 498 (1988) (Stevens, J., dissenting). Justice Stevens's recognition of the hostility inherent in the use of the picket line undermines his argument that the Brookfield ordinance would ban a fifth-grader from carrying a sign 
conducted "peacefully."119 Such potentially dangerous conduct is not "beyond the reach of uniform and nondiscriminatory regulation,"120 although the messages sought to be communicated thereby are protected under the First Amendment. ${ }^{121}$ Therefore, although the messages that the picketers seek to communicate are protected speech, ${ }^{122}$ the picket line itself is "inseparably something more and different." 123 It is this "something more"-the

reading "Get Well Charlie-Our Team Needs You" in front of the residence of a sick classmate, id. at 496; such a beneficent display would not be a "picket." See Thomas v. City of Indianapolis, 145 N.E. 550, 552 (Ind. 1924) ("[T]he word 'picket' is borrowed from the nomenclature of warfare, and is strongly suggestive of a hostile attitude . . ..").

119. In fact, as one court noted, "There is and can be no such thing as peaceful picketing, any more than there can be chaste vulgarily, or peaceful mobbing, or lawful lynching. When men want to converse or persuade, they do not organize a picket line." Atchinson, T. \& S.F. Ry. v. Gee, 139 F. 582 , 584 (C.C.S.D. Iowa 1905).

120. Carey v. Brown, 447 U.S. 455,470 (1980).

121. See, e.g., Frisby, 487 U.S. at 479; Gregory v. City of Chicago, 394 U.S. 111, 125 (1969) (Black, J., concurring) ("Speech and press are, of course to be free, so that public matters can be discussed witb impunity. But picketing and demonstrating can be regulatcd like other conduct of men."); Cox v. Louisiana, 379 U.S. 536, 555 (1965) ("We emphatically reject the notion urged by appellant that the First and Fourteenth Amendments afford the same kind of freedom to those who would communicate ideas by conduct such as patrolling, marching, and picketing on streets and highways, as these amendments afford to those who communicate ideas by pure speech."); Hughes v. Superior Court, 339 U.S. 460, 464 (1950) ("The Constitution does not demand that the element of communication in picketing prevail over the mischief furthered by its use in these situations."); Carpenters \& Joiners Union of Am. Local No. 213 v. Ritter's Cafe, 315 U.S. 722, 725 (1942) ("[We reject the claim] that there is to be found in the Due Process Clause of the Fourteenth Amendinent a constitutional command that peaceful picketing must be wholly immune from regulation by the community in order to protect the general interest, that the states must be powerless to confine the use of this industrial weapon within reasonable bounds.").

It is especially interesting to note that Justice Black, who firmly believed in a literal, absolutist interpretation of the First Ainendinent, see Everette E. Dennis \& Donald M. Gillnor, Hugo L. Black: "No Law' Means 'No Law,'” in JUSTICE HUgo BLACK AND THE FIRST AMENDMENT 3 (Everette E. Dennis et al. eds., 1978), supported restrictions on picketing.

Plainly, however, no mandate in our Constitution leaves States and governmental units powerless to pass laws to protect the public from the kind of boisterous and threatening conduct [picketing] that disturbs the tranquility of spots selected by the people... for homes, wherein they can escape the hurly-burly of the outside business and political worlds .... .

Gregory, 394 U.S. at 118 (Black, J., concurring); see also Cox, 379 U.S. at 578 (Black, J., concurring in part and dissenting in part) ("Picketing, though it may be utilized to communicate ideas, is not speech, and therefore is not of itself protected by the First Amendment.").

122. Frisby, 487 U.S. at 479 (noting that "debate on public issues"-political speech-is exactly the type of expression that the First Amendinent was designed to protect).

123. Hughes, 339 U.S. at 464. 
conduct of picketing rather than its message-that government may regulate in the pursuit of other valid interests.

\section{Content-Based Restrictions and the Requirement of Neutral-} ity. If the government may permissibly regulate the conduct aspects of picketing, it still must do so in a "uniform and nondiscriminatory" way. ${ }^{124}$ Although government may impose reasonable regulations on expressive conduct even if such regulations incidentally infringe on speech, it may not engage in censorship under the guise of regulating conduct. ${ }^{125}$

Typically, a court will find a regulation to be content-based when the regulation provides an exemption for certain kinds of speech. ${ }^{126}$ The defendants in Valenzuela relied on a counterargument: that residential picketing injunctions are content-based because they apply only to a discrete group of people and therefore only to those messages which that group of people seeks to express. They claimed that the plaintiffs sought to enjoin the picketing because they disagreed with the picketers' views and wanted to silence debate on a topic of public concern. ${ }^{127}$

It may be true, in fact, that the targeted resident disagrees with the picketers' message; the picket line itself symbolizes that disagreement. The harm in residential picketing, however, is not based on the content of the message. Indeed, the targeted resident may often face similar pickets at her place of business or elsewhere in her public life. ${ }^{128}$ The harm of residential picketing is "the very presence of an unwelcome visitor at the home." 129 It is

124. Carey, 447 U.S. at 470 .

125. See Police Dep't v. Mosley, 408 U.S. 92, 96 (1972) ("The essence of . . . censorship is content control .... [Government] may not select which issues are worth discussing or debating in public facilities.").

126. In the context of picketing, the Court has consistently struck down regulations that exempt certain categories of issues-typically labor disputes-from sanctions. For example, in Mosley, the Court found a city ordinance prohibiting picketing near school facilities during school hours except for "the peaceful picketing of any school involved in a labor dispute," id. at 93 , to violate the requirement of content-neutrality, id. at 102 .

127. Petitioners' Application for Writ of Error at 31-33, Valenzuela v. Aquino, 853 S.W.2d 512 (Tex. 1993) (No. D-0740).

128. Valenzuela v. Aquino, 800 S.W.2d 301; 305-06 (Tex. Ct. App. 1990), rev'd in part, 853 S.W.2d 512 (Tex. 1993).

129. Frisby v. Schultz, 487 U.S. 474, 487 (1988) (quoting Carey v. Brown, 447 U.S. 455, 478 (1980) (Rehnquist, J., dissenting)). 
this physical presence-the form of communication rather than its substance-that courts may enjoin. ${ }^{130}$

That the picketers have only a single message that they wish to advance is largely irrelevant. Once the plaintiff has shown actual harm to her privacy interests, the presence of this same group of picketers will perpetuate the harm regardless of the message the picketers wish to convey. ${ }^{131}$ Under facially content-neutral injunctions, ${ }^{132}$ therefore, the named defendants cannot communicate any message-supportive, hostile, or neutral with regard to the plaintiff-through picketing.

\section{TOWARd A New Definition of Focused Picketing: RESIDENTIAL PICKETING INJUNCTIONS AS TIME, PLACE, AND MANNER REgULATIONS}

If injunctions against residential picketing are not prior restraints, they are subject to analysis under the time, place, and manner doctrine. Time, place, and manner analysis requires the court to balance the respective rights of the parties, giving special emphasis to the proposition that government should not infringe on First Amendment rights any more than is absolutely necessary. A regulation that is "content-neutral, ... narrowly tailored to serve a significant government interest, and leave[s] open ample alternative channels of communication"133 is an appropriate time, place, and manner regulation. As shown above, residential picketing injunctions are content-neutra $1^{134}$ and protect a significant government interest in residential privacy. ${ }^{135}$ Based on an expanded definition of focused picketing, they satisfy the remaining elements of time, place, and manner analysis as well.

130. See id.

- 131. See id. at 486 (noting that picketing "inherently and offensively intrudes on residential privacy"); see also Valenzuela, 800 S.W.2d at 306 (rejecting argument that contentneutral injunction offended equal protection because it applied only to named defendants).

132. See Burson v. Freeman, 112 S. Ct. 1846, 1850-51 (1992) (noting that one aspect of the test of permissibility is whether regulation is facially content-neutral).

133. Perry Educ. Ass'n v. Perry Local Educators' Ass'n, 460 U.S. 37, 45 (1983); see also Ward v. Rock Against Racism, 491 U.S. 781, 791 (1989); Clark v. Community for Creative Non-Violence, 468 U.S. 288, 293 (1984); Heffron v. International Soc'y for Krishna Consciousness, Inc., 452 U.S. 640, $647-48$ (1981).

134. See supra subsection II(B)(2).

135. See supra Section I(B). 
Time, place, and manner analysis was central to the U.S. Supreme Court's holding in Frisby $v$. Schultz. ${ }^{136}$ In balancing the rights of the parties in Frisby, the Court determined that the government could enact a "complete ban" on focused picketing in the interest of protecting residential privacy. ${ }^{137}$ Yet the Court interpreted the ordinance's prohibition of focused picketing extremely narrowly as "picketing taking place solely in front of a particular residence."138 The complete ban that the Court sanctioned, therefore, was far less protective of the right to residential privacy than the Court's characterization of that right as "of the highest order in a free and civilized society"139 would indicate was appropriate.

The defendants in the post-Frisby residential picketing injunction cases argue that Frisby defines the outer boundaries of permissible regulations and that courts may impose no greater restriction on speech than that specifically found permissible in Frisby. In fact, just the opposite is true: Frisby is not the last word on permissible residential picketing regulations but only the first. Under a definition of focused picketing, based on Frisby, that looks to the picketers' intent rather than to the length of their picket line, complete bans on picketing within several hundred feet of a particular home are entirely appropriate time, place, and manner regulations.

\section{A. A Broader Definition of Focused Picketing}

In Frisby, the Court met the requirement of narrow tailoring by construing the anti-picketing ordinance to ban only focused picketing. ${ }^{140}$ Such picketing could be completely banned ${ }^{141}$ and still meet the narrow tailoring requirement because the picketers' physical presence itself created the regulable evil. ${ }^{142}$

136. 487 U.S. 474 (1988).

137. Id. at $485-86$.

138. Id. at 483 (emphasis added).

139. Id. at 484 (quoting Carey v. Brown, 447 U.S. 455, 471 (1980)).

140. Id. at 486.

141. Cf. id. at 494 (Brennan, J., dissenting) (asserting that government could legitimately regulate the size, hours, or noise level of the pickets but could not prohibit all picketing).

142. Id. at 487 (fimding that "the 'evil' of targeted residential picketing, 'the very presence of an unwelcome visitor at the home,' [was] 'created by the medium of expression itself ") (citations omitted). 
The central issue in post-Frisby injunction cases such as Valenzuela v. Aquino ${ }^{143}$ is whether focused picketing is only "picketing taking place solely in front of a particular residence"144 or whether the Frisby definition is only one of several that could describe focused picketing. The defendants claim that because their picket lines move up and down the street, often in front of an entire block or more of houses, they are engaging not in prohibited focused picketing but in general marching, which Frisby expressly permitted. ${ }^{145}$

This argument is problematic because it focuses only on one specific example of a more general definition of focused picketing. The Court in fact defined focused picketing in more general terms as picketing that was designed not to "disseminate a message to the general public, but to intrude upon the targeted resident, and to do so in an especially offensive way." 146 The "type of focused picketing"147 that the Frisby ordinance banned-picketing taking place solely in front of a single residence-was an example of such intrusive behavior, but it is not the only possible example. It is possible, in fact, to imagine that other forms of picketing that do not involve standing stationary in front of a single home nevertheless could be targeted to. intrude on the residents of that home. For these picketers return not to random or varied places throughout the city or even to different areas of a single neighborhood, as those seeking the widest possible audience for reception of their message would, but to the same location time and time again. The signs name a particular individual, ${ }^{148}$ sometimes the picket line slows down as it passes in front of that particular individual's home; ${ }^{149}$ the defendants in Valenzuela even carried out surveillance of the plaintiffs' home with binoculars and a video camera. ${ }^{150}$ This is focused picketing, as offensive and intrusive as that

143. 800 S.W.2d 301 (Tex. Ct. App. 1990), rev'd in part, 853 S.W.2d 512 (Tex. 1993).

144. Frisby, 487 U.S. at 482.

145. Petitioners' Application for Writ of Error at 30-31, Valenzuela v. Aquino, 853

S.W.2d 512 (Tex. 1993) (No. D-0740).

146. Frisby, 487 U.S. at 486.

147. Id. (emphasis added).

148. Valenzuela v. Aquino, 800 S.W.2d 301, 304 (Tex. Ct. App. 1990), rev'd in part, 853 S.W.2d 512 (Tex. 1993).

149. See Plaintiffs-Appellees' Brief at 3, Kaplan v. Prolife Action League, 431 S.E.2d 828 (N.C. Ct. App. 1993), appeal docketed, No. $9218 S C 459$ (N.C. Aug. 20, 1993).

150. Response of Respondents to Application of Petitioners ior Writ of Error at 5, Valenzuela v. Aquino, 853 S.W.2d 512 (Tex. 1993) (No U-0740). 
identified in Frisby and equally subject to regulation by a complete ban broad enough to remove the source of the offense. ${ }^{151}$

A broader ban than the one the Court specifically approved in Frisby also may be appropriate given the Frisby Court's recognition that focused picketing was impermissibly destructive of the environment thought appropriate to the home. ${ }^{152}$ Some courts have justified residential picketing injunctions on an interpretation of Frisby that accounts for the special nature of the home. ${ }^{153}$ Such an approach is premised on the idea that "[t]he nature of a place, 'the pattern of its normal activities, dictate the kinds of regulations of time, place, and manner that are reasonable." "154 Under this approach, the definition of what constitutes focused picketing expands to include not only picketing located physically in front of a single home but also picketing of a broader geographic scope that nonetheless is directed at a single home. This approach takes the underlying rationale of Frisby-that focused residential picketing is inherently offensive ${ }^{155}$ - to its logical conclusion. If the evil of such behavior lies in singling out a particular individual, that evil exists whenever the purpose of the picket is to focus pressure on an individual in her home, regardless of the amount of space used to accomplish that goal.

It is the intent of the picketers, not the distance the picket line travels, that defines focused picketing. The logic of Frisby, with its focus on the sanctity of the home and the activities appropriate to it, suggests that a broader definition of focused picketing is warranted. If focused picketing is more broadly defined, courts may ban it whenever picketers use the residential forum to intrude on residential privacy rather than to disseminate a message to the general public.

151. Frisby, 487 U.S. at $485-88$.

152. Id. at $484,486-87$.

153. See, e.g., Valenzuela v. Aquino, 800 S.W.2d 301, 305 (Tex. Ct. App. 1990) (noting that "[t]he home should be a sanctuary insulated from as many external pressures as possible"), rev'd in part, 853 S.W.2d 512 (Tex. 1993).

154. Grayned v. City of Rockford, 408 U.S. 104, 116 (1972) (quoting Charles A. Wright, The Constitution on the Campus, 22 VAND. L. REv. 1027, 1042 (1969)) (footnote omitted).

155. Frisby, 487 U.S. at 486. 


\section{B. Narrow Tailoring}

Even if a significant government interest in protecting privacy justifies regulation of focused picketing, a regulation cannot restrict more speech than is necessary to protect that interest. ${ }^{156} \mathrm{~A}$ proposed regulation must be narrowly tailored to serve the significant government interest that justifies the regulation. This requirement does not demand that the regulation be the least restrictive means of accomplishing the government's goals, in the sense that no other imaginable alternative exists that is less burdensome on speech; it means only that the chosen restriction is "not substantially broader than necessary to achieve the government's interest." 157

To be valid, a residential picketing injunction could not be so broad that it swept within its ambit both focused picketing meant to intrude on residential privacy and other types of protests that have a truly communicative purpose and intent. Although courts have been rightfully hesitant to create injunctions that could effectively encompass an entire neighborhood, ${ }^{158}$ protected areas of several hundred feet around the targeted residence are entirely consistent with the requirement of narrow tailoring because they do no more than eliminate a proven harm. As a facial challenge, Frisby only offered the building blocks; courts themselves must fashion appropriate injunctions based on proven harms to residential privacy.

156. Perry Educ. Ass'n v. Perry Local Educators' Ass'n, 460 U.S. 37, 45 (1983).

157. Ward v. Rock Against Racism, 491 U.S. 781, 800 (1989). The least restrictive means test has been criticized as too subjective and subject to manipulation. See Illinois State Bd. of Elections v. Socialist Workers Party, 440 U.S. 173, 188-89 (1979) (Blackmun, J., concurring) (stating that any creative judge could always devise some less drastic alternative); William E. Lee, Lonely Pamphleteers, Little People, and the Supreme Court: The Doctrine of Time, Place, and Manner Regulations of Expression, 54 GEO. WASH. L. REV. 757, 792-99 (1986).

158. See Northeast Women's Ctr., Inc. v. McMonagle, 939 F.2d 57, $66-67$ \& n.14 (3d Cir. 1991) (fmding lower court's injunction creating a 2500 -foot protected zone around the targeted residence of doubtful constitutionality given Frisby's single residence language and modifying the injunction to ban picketing within 500 feet of the doctor's residence, although leaving open the possibility that, on proof of extraordinary circumstances, the 2500-foot ban would be appropriate); Valenzuela v. Aquino, 763 S.W.2d 43, 45 (Tex. Ct. App. 1988) (dissolving temporary injunction creating a picket-frec zone of one-half mile around plaintiffs' residence). 


\section{Ample Alternative Channels}

Finally, a valid time, place, and manner regulation must preserve ample alternative channels of communication. ${ }^{159}$ The requirement of ample alternative channels is linked to the requirement of narrow tailoring and ensures that in closing off one forum, the government does not strangle speech entirely. Other opportunities to communicate the message must remain intact.

In Frisby, the Court found that the challenged ordinance, narrowly construed to ban only focused picketing, preserved ample alternative channels because it could not be read to prohibit "[g]eneral marching through residential neighborhoods, or ... walking a route in front of an entire block of houses." $160 \mathrm{Be}$ cause their picket line extended beyond the property lines of a single home, the defendants in Valenzuela characterized their behavior as general marching and claimed that an injunction prohib- . iting such marching failed to preserve ample alternative channels of communication. ${ }^{161}$

Yet, as already noted, ${ }^{162}$ the distinction between focused picketing and general marching is based on intent, not on the mere physical parameters of the picket line. ${ }^{163}$ There is no right

159. Perry, 460 U.S. at 45 .

160. Frisby v. Schultz, 487 U.S. 474,483 (1988).

161. Petitioners' Application for Writ of Error at 30, Valenzuela v. Aquino, 853 S.w.2d 512 (Tex. 1993) (No. D-0740).

162. See supra Section III(A).

163. Frisby, 487 U.S. at 486 ("The type of picketers banned by the Brookfield ordinance generally do not seek to disseininate a message to the general public, but to intrude upon the targeted resident, and to do so in an especially offensive way.").

The Supreme Court's decision in Gregory v. City of Chicago, 394 U.S. 111 (1969), does not undermine this assertion. Gregory, which involved a civil rights demonstration, is distinguishable from Valenzuela and the other recent residential picketing cases on several grounds. First, the march in Gregory covered a five-mile route that began at the Chicago Loop District and culminated in the mayor's neighborhood. Id. at 115 (Black, J., concurring). Such a deinonstration is much more akin to a general march, intended to generate publicity, than to focused picketing that merely travels one or two blocks on either side of a targeted residence, intended to physically intimidate the targeted resident. Second, Gregory involved the picketing of a public official's hoine. Id. The Valenzuela appellate court recognized that the plaintiffs there were not public officials and therefore had a reasonable expectation of privacy within their home. Valenzuela v. Aquino, 800 S.W.2d 301, 307 (Tex. Ct. App. 1990), rev'd in part, 853 S.W.2d 512 (Tex. 1993); see also Walinsky v. Kennedy, 404 N.Y.S.2d 491, 497 (Sup. Ct. 1977). Lastly, the protestors in Gregory had not been shown to have been responsible for any actionable harm; it was the crowd of spectators who caused the melee that resulted in the protestors arrest. Gregory, 394 U.S. at 128-29 (Black, J., appendix to concurring opinion) (quoting Chicago v. 
to engage in focused picketing no matter how far the picket line travels. Residential picketing injunctions, therefore, may satisfy the ample alternative channels requirement as long as they maintain other opportunities for communication that do not involve the invasion of residential privacy.

Residential picketing injunctions ban a single form of behavior-picketing-in a discrete and well-defined area. They do not prevent picketing at other locations, e.g., the resident's place of business, ${ }^{164}$ the entrance to her neighborhood, or other public

Gregory, 233 N.E.2d 422, 424-26 (Ill. 1968)). The picketers in Valenzuela and similar resideritial picketing cases are not so blameless. See supra note 94.

164. Valenzuela, 800 S.W.2d at 306 . Some lower courts have granted residential picketing injunctions on the grounds that the targeted resident's business, and not the home, is the true situs of the dispute. See, e.g., K-T Marine v. Dockbuilders Local Union 1456, 597 A.2d 540, 543 (N.J. Super. Ct. App. Div. 1991) (upholding the lower court's ability to enjoin picketing at a company president's home on the grounds that it was "a neutral dwelling having no connection with the labor controversy"); Town of Barrington v. Blake, 568 A.2d 1015, 1021 (R.I. 1990) (construing a town ordinance as meeting the ample alternatives requirement on the grounds that, inter alia, "picketers are also provided the opportunity to picket at a place of business, which is generally a more effective forum to disseminate their views, unless the picketers' objective is only to harass or intimidate an individual").

The idea that picketing could be restricted to the situs of the dispute is not a new one. See Carpenter's \& Joiners Union of Am. Local No. 213 v. Ritter's Cafe, 315 U.S. 722 (1942). In Ritter's Cafe, striking workers picketed the respondent's business after he entered into a construction contract with a general contractor who did not hire union labor for the job. The construction contract was otherwise unrelated to the respondent's restaurant business. Id. at 722-23. In upholding the lower court's decision to enjoin the pickets, the Supreme Court held that

recognition of peaceful picketing as an exercise of free speech does not imply that the states must be without power to confine the sphere of communication to that directly related to the dispute. Restriction of picketing to the area of the industry within which a labor dispute arises leaves open to the disputants other traditional modes of communication. To deny to the states the power to draw this line is to write into the Constitution the notion that every instance of peaceful picketing-anywhere and under any circumstances-is necessarily a phase of the controversy which provoked the picketing.

Id. at 727-28. The Court said that due process did not require the states to tolerate "conscription of neutrals." Id. at 728.

Moreover, such an argument is implicit in then-Justice Rehnquist's dissent in Carey v. Brown, on which the Court rehed in fornulating its opinion in Frisby. See Frisby, 487 U.S. at 486-87 (citing Carey v. Brown, 447 U.S. 455, $478-79$ (1980) (Rehnquist, J., dissenting)). In Carey, the Court struck down as a content-based restriction an ordinance that banned residential picketing except when the residence also was used as a place of business. Carey, 447 U.S. at 457 . In dissent, Justice Rehnquist insisted, "Our cases clearly support a State's authority to design the permissibility of picketing in relation to the use to which a particular building is put," id. at 482 (Rehnquist, J., dissenting), and chastised the Court for putting such substantial obstacles in the path of state efforts to protcet residential privacy: "it is not for us to supervise the linits the legislature may impose in 
places she frequents. Nor do they prohibit other forms of communication, e.g., leafletting, door-to-door solicitation, or mailings, that have not been shown to invade residential privacy. ${ }^{165}$

Defendants may counter that these forms of expression deprive them of the best forum in which to disseminate their message, ${ }^{166}$ but this argument only reveals their true intent. If the picketers' aim were solely to communicate a message, surely some or all of the alternate means suggested above could serve that goal equally well. ${ }^{167}$ The real benefit of residential picketing, by contrast, is its ability to create a highly offensive invasion of privacy and thereby to hasten compliance with the picketers' demands. ${ }^{168}$ Because " $[t]$ he picket line elicits conditioned responses"-principally anxiety and fear-"'the picket signs might just as effectively be blank."169

safeguarding the steadily narrowing opportunities for serenity and reflection." Id. at 489 (quoting Kovacs v. Cooper, 336 U.S. 77, 97 (1949) (Frankfurter, J., concurring)). In comparison, in cases in which picketing has occurred at the plaintiff's place of business, courts have struck down injunctions as prior restraints. See, e.g., In re Stonegate Security Servs., Ltd., 56 B.R. 1014, 1020 (N.D. Ill. 1986) (noting "the lack of any showing of a damaging impact on a compelling, countervailing interest").

165. This is not to say that such practices might not, if abused, become an enjoinable source of harm. See Rowan v. Únited States Post Office Dep't, 397 U.S. 728, 738 (1970) (holding that the state could protect residential privacy by allowing residents to refuse unwanted inailings); see also Northeast Women's Ctr., Inc. v. McMonagle, 745 F. Supp. 1082,1090 (E.D. Pa.) (injunction keeping picketers away from entrance to abortion clinic justified on basis of proven harm to patients), modified, 749 F. Supp. 695 (E.D. Pa. 1990), aff', 939 F. 2d 57 (3d Cir. 1991).

166. See Frisby, 487 U.S. at 486 ("[E]ven if some such picketers have a broader communicative purpose, their activity nonetheless inherently and offensively intrudes on residential privacy.").

In addition, one must remember that although the residential street in front of the targeted home may be the best forum for picketers to conmunicate their message, it is the only forum in which residents can create a private home environment. See Klebanoff v. McMonagle, 552 A.2d 677, 682 (Pa. Super. Ct. 1988).

167. See Barrington, 568 A.2d at 1021 ("[P]icketers are also provided the opportunity to picket at a place of business, which is generally a more effective forum to disseminate their views, unless the picketers' objective is only to harass or intimidate an individual.").

168. Bakery \& Pastry Drivers \& Helpers Local 802 v. Wohl, 315 U.S. 769, 776 (1942) (Douglas, J., concurring) (finding that "the very presence of a picket line may induce action of one kind or another, quite irrespective of the nature of the ideas which are being disseminated"); see also Carey, 447 U.S. at 485 (Rehnquist, J., dissenting) ("[Harassment] is not the type of influence that a democratic society has traditionally held high as a part of the Bill of Rights.").

169. Alfred Kamin, Residential Picketing and the First Amendment, 61 N.W. U. L. REV. 177, 198, 199 (1966). 
Residential picketing injunctions leave open ample alternative channels of communication because they bar only those forms of expression that have been shown to cause harm when practiced in a particular place. Although it is true that "one is not to have the exercise of his liberty of expression in appropriate places abridged on the plea that it may be exercised in some other place,"170 the place chosen must in fact be appropriate. ${ }^{171}$ Although picketing is undoubtedly appropriate in other places, the home simply is not an appropriate place for this particular form of expression. Residential picketing is "merely a right thing in the wrong place,-like a pig in the parlor instead of the barnyard."172 As such, courts may enjoin residential picketing consistent with the ample alternative channels requirement.

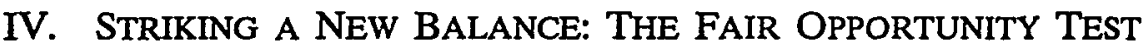

In granting a permanent injunction, a court undertakes a balancing analysis to determine, based on the particular facts of each case, the appropriate content and scope of the injunction. ${ }^{173}$ In residential picketing cases, two very important rights-free speech and residential privacy-clash. When expressive conduct has not yet taken place, harms to privacy interests are speculative, and, absent exceptional circumstances, the court may not impose a prior restraint on that conduct. ${ }^{174}$ The first instance of residential picketing, however, creates an invasion of privacy. ${ }^{175}$ If the picketing is repeated, injuries to privacy interests begin to accumulate.

170. Schneider v. State, 308 U.S. 147, 163 (1939) (emphasis added).

171. See Note, supra note 116, at 137 ("The number of picketers, the time of day, the intensity of traffic, and other variables of time and manner do not alter the character of the private residence as unsuitable for protest activity."). But of. Daniel M. Taubman, Comment, Picketers at the Doorstep, 9 HARV. C.R.-C.L. L. REV. 95, 105 (1974) ("Certainly, the content of the message sought to be delivered need not be at all related to the site of its reception.").

172. FCC v. Pacifica Found., 438 U.S. 726, 750 (1978) (quoting Euclid v. Ambler Realty Co., 272 U.S. 365, 388 (1926)).

173. See Weinberger v. Romero-Barcelo, 456 U.S. 305, 311-12 (1982); El Greco Leather Prods. Co. v. Shoe World, Inc., 599 F. Supp. 1380, 1390 (E.D.N.Y. 1984) (holding that if plaintiff has succeeded on the merits of her case, "the Court must then decide whether the 'balance of the equities' favor [sic] injunctive relief, and if so, what form it should take."), rev'd on other grounds, 806 F.2d 392 (2d Cir. 1986), cert denied, 484 U.S. 817 (1987).

174. See supra subsection $\operatorname{II}(\mathrm{A})(1)$.

175. See Public Utils. Comm'n v. Pollack, 343 U.S. 451, 469 (1952) (Douglas, J., dissenting) ("Once privacy is invaded, privacy is gone."). 
At some point, the balance between free speech and residential privacy begins to tip in favor of privacy; at this point, courts may enjoin picketing to protect privacy.

The question, then, is at what point the balance is tipped. Under the intent-centered definition of focused picketing suggested above, the balance must tip when the purpose to communicate a message becomes subsumed by the purpose simply to invade residential privacy for the sake of the invasion. Courts are justified in drawing a distinction between communication and physical and psychological intimidation, between free speech and harassment. ${ }^{176}$ Drawing this distinction does not infer that the message is no longer valuable but only that the conduct has becoine so harmful that courts may enjoin it despite incidental effects on the message. Courts can draw this line based on a determination of whether the picketers have had a "fair opportunity" to coinmunicate their message. ${ }^{177}$

\section{A. The Distinction Between Communication and Harassment}

The evil identified in Frisby is that of physically intruding on residential privacy simply to create a psychological harm rather than to disseminate a message. ${ }^{178}$ If this is the case, then residential picketing, peaceful or otherwise, should be enjoinable wherever it is pursued more for its intrusive than for its communicative effects. ${ }^{179}$

Dissenting in Frisby, Justice Brennan took special exception to the Court's formulation of a test based on the speaker's intent to coerce. $\mathrm{He}$ insisted that the Court's precedents clearly indicated that an intent to coerce the listener does not remove a speech act from the realm of the First Amendinent; ${ }^{180}$ as long as picketing

176. See, e.g., Franklin Chalfont Assocs. v. Kalikow, 573 A.2d 550, 556 (Pa. Super. Ct. 1990) (finding an injunction against picketing that was not shown to be "physically intiunidating" to be an unconstitutional prior restraint).

177. This proposed test is intended to inform the application of the time, place,-and manner analysis, not to replace it. It also ensures that residential picketing injunctions do not run afoul of the prior restraint doctrine, since residents must demonstrate an actual harm before courts may issue injunctions under the test.

178. See Frisby v. Schultz, 487 U.S. 474, 486 (1988); id. at 498 (Stevens, J., dissenting).

179. Id. at 486 (stating that "even if some such picketers have a broader communicative purpose, their activity nonetheless inherently and offensively intrudes on residential privacy").

180. Id. at 495 (Brennan, J., dissenting) (citing Organization for a Better Austin v. Keefe, 402 U.S. 415, 419 (1971)). American courts have recognized this principle only 
is peaceful, argued Justice Brennan, its goal is "not fundamentally different from the function of a newspaper."181

There are two problems with this argument. First, it ignores the important distinction between pure speech, such as publishing a newspaper, and expressive conduct, such as picketing, which government may regulate to protect residential privacy. ${ }^{182}$ Although a state is powerless to regulate a newspaper editorial that might be offensive, if the paper subsequently began sending out voluminous mailings expounding its offensive position, ${ }^{183}$ or broadcasting the offensive message over the radio, ${ }^{184}$ or renting a sound truck to blare the offensive message throughout residential neighborhoods, ${ }^{185}$ the courts surely could remedy such behavior under the Court's precedents.

Second, Justice Brennan's choice of the word "coercion" to describe a permissible goal of communication and a protectible First Amendment interest is problematic. This reasoning ignores an important distinction between persuasion, which focuses on the message alone, and physical and psychological intimidation, in which the speaker resorts to a highly coercive form of conduct as a vehicle for her message. Even peaceful picketing, especially when repeated and especially when taking place at the home, is not merely persuasive in the same sense as a newspaper editorial is persuasive; ${ }^{186}$ at some point, the conduct itself becomes physi-

fairly recently. Through the 1960 s, courts routinely offered relief to residents from picketing at their homes on the grounds that the picketers' motivation was coercive rather than informational. See, e.g., Hughes v. Superior Court, 339 U.S. 460, 465 (1950); Hall v. Hawaiian Pineapple Co., 72 F. Supp. 533, 537 (D. Haw. 1947); State v. Zanker, 229 N.W. 311, 311-12 (Minn. 1930); Evening Times Printing \& Publishing Co. v. American Newspaper Guild, 199 A. 598, 604 (N.J. 1938); Walinsky v. Kennedy, 404 N.Y.S.2d 491, 497 (Sup. Ct. 1977); Hebrew Home \& Hosp. for Chronic Sick, Inc. v. Davis, 235 N.Y.S.2d 318, 323-24 (Sup. Ct. 1962); Pipe Machinery Co. v. De More, 76 N.E.2d 725, 726 (Ohio Ct. App. 1947).

181. Keefe, 402 U.S. at 419 (citation omitted).

182. See supra subsection II(B)(1).

183. Rowan v. Umited States Post Office Dep't, 397 U.S. 728, 738 (1972) (allowing homeowners to refuse unwanted mailings).

184. FCC v. Pacifica Found., 438 U.S. 726, 748-49 (1978) (allowing states to prohibit offensive broadcasts on grounds that such broadcasts intrude on residential privacy).

185. Kovacs v. Cooper, 336 U.S. 77, 87-89 (1949) (upholding town ordinance banning the use of sound trucks in residential neighborhoods).

186. See Carey v. Brown, 447 U.S. 455, 485 (1980) (Rehnquist, J., dissenting) ("[Harassment] is not the type of influence that a democratic society has traditionally held high as a part of the Bill of Rights."); Kamin, supra note 169, at 231 ("If public decisions are to be made in this way, the group which can bring the greatest amount of physical pow- 
cally and psychologically intimidating, regardless of the message. ${ }^{187}$ The point at which picketing to communicate a message begins to tip over into harassment solely for harassment's sake-even if ostensibly peaceful ${ }^{188}$-is the point at which courts may enjoin it.

\section{B. Tipping the Balance: The Fair Opportunity Test}

If courts may draw a permissible distinction between an intent to persuade and an intent to physically and psychologically intimidate in deciding whether or not to grant a residential picketing injunction, they must have some basis on which to draw this distinction. The standard for granting an injunction requires courts to balance the competing rights of free speech and residential privacy by weighing the harm to the defendant if the injunction is granted against the harm to the plaintiff if it is denied. This Section suggests that one possible way to balance these harms is to determine whether the picketers have had a "fair opportunity" to communicate their message to the targeted resident. ${ }^{189}$

er to bear upon officials will see its views prevail. A government somewhere might function this way-but it would not be a democracy."); see also Atchinson, T. \& S.F. Ry. v. Gee, 139 F. 582, 584 (C.C.S.D. Iowa 1905) ("When men want to converse or persuade, they do not organize a picket line."); Bering v, SHARE, 721 P.2d 918, 928 (Wash. 1986) (en banc) (fmding that the heightened "coercive impact" of having to confront abortion protestors when entering a clinic threatens the rights of women to choose to have legal abortions and the rights of doctors to choose to perform them), cert. dismissed, 479 U.S. 1050 (1987).

187. See Frisby v. Schultz, 487 U.S. 474, 486 (1988) (noting that the goal of the residential picketer is not to communicate with the general public but to invade residential privacy).

188. See Atchinson, $139 \mathrm{~F}$. at 584 ("There is and can be no such thing as peaceful picketing, any more than there can be chaste vulgarity, or peaceful mobbing, or lawful lynching."); Bakery \& Pastry Drivers \& Helpers Local 802 v. Wohl, 315 U.S. 769, 775 (1942) ("A state is not required to tolerate in all places and all circumstances even peaceful picketing by an individual.").

189. Justice Stevens suggested such a theory in his dissenting opinion in Frisby.

I do not believe that picketing for the sole purpose of inposing psychological harm on a family in the shelter of their home is constitutionally protected. I do believe, however, that the picketers have a right to coinmunicate their strong opposition to abortion to the doctor, but after they have had a fair opportunity to coinmunicate that message, I see little justification for allowing them to remain in front of his home and repeat it over and over again simply to harm the doctor and his family.

Frisby, 487 U.S. at 498 (Stevens, J., dissenting); see also Franklyn S. Haiman, Speech v. Privacy: Is There a Right Not To Be Spoken To?, 67 N.W. U. L. REV. 153, 193 (1972) (suggesting that speakers be given at least "one shot" at an audience before the law may protect the audience's right to escape the communication). 
The definition of fair opportunity is a fact-specific one designed to protect protestors' right to communicate their message. This definition explicitly recognizes, however, that once picketers have had such an opportunity to communicate, the importance of picketing as a vehicle for disseminating the message begins to wane. With each additional instance, the conduct becomes more and more an end in itself. At some point, therefore, courts are justified in determining that the desire to "intrude on the targeted resident" 190 has eclipsed any "broader communicative purpose"191 that the picketers still may possess.

The most salient factor that courts should consider in determining whether picketers have received a fair opportunity to communicate their message is repetition. The fair opportunity theory assumes that repetition is evidence of a purpose to physically and psychologically mtimidate and that with each repeated incident of residential picketing, communicative goals become less important than coercive ones. In some circumstances, however, a single incidence of residential picketing, coupled with an expressed intent to return, may be sufficient to trigger a court's protection. ${ }^{192}$ More frequently, the picketing will have occurred numerous times over a period of weeks, ${ }^{193}$ months, ${ }^{194}$ or even more than a year ${ }^{195}$ before the resident seeks to enjoin it. In such circumstances, the burden may shift to the picketer to show that her conduct is not intended to physically and psychologically intimidate.

Once the presumption of an intent to intimidate is raised, other factors may strengthen or weaken it. Such factors could include the size of the crowd, the duration of the picket, the amount of time between pickets, whether the protestors have picketed the resident before in other locations, the demonstrated level of harm to the resident and her fainily, and the picketers' demonstrated good faith in attempting to communicate with the particular resident. ${ }^{196}$ This list is certainly not exclusive; it is

190. Frisby, 487 U.S. at 486.

191. Id.

192. See Walinsky v. Kennedy, 404 N.Y.S.2d 491 (Sup. Ct. 1977).

193. See Response of Respondents to Application of Petitioners for Writ of Error at

5, Valenzuela v. Aquino, 853 S.W.2d 512 (Tex. 1993) (No. D-0740).

194. See Klebanoff v. McMonagle, 552 A.2d 677, 677 (Pa. Super. Ct. 1988).

195. See Plaintiffs-Appellees' Brief at 2, Kaplan v. Prolife Action League, 431 S.E.2d 828 (N.C. Ct. App. 1993), appeal docketed, No. $9218 S C 459$ (N.C. Aug. 20, 1993).

196. Thus, for example, picketers who purposely chose to picket during those times of day when the targeted resident was at work but her spouse and/or children were at home 
meant only to be suggestive of those factors that could indicate that picketers have had a fair opportunity to communicate their message and that picketing is no longer being pursued principally to communicate.

It is interesting to note that in some respects the fair opportunity model is less restrictive of speech than the ordinance upheld in Frisby. The fair opportunity model gives protestors an opportunity to use the residential forum, even for focused picketing, for as long as it takes to accomplish the valid purpose of communicating a message. The ordinance approved in Frisby, by contrast, completely prohibited focused picketing before it ever occurred. Moreover, the fair opportunity model does not go beyond the limits of other important residential privacy decisions. For example, in FCC v. Pacifica Foundation ${ }^{197}$ and Kovacs v. Cooper, ${ }^{198}$ the Court did not require the resident to absorb even the initial impact of speech before her privacy could be protected; ${ }^{199}$ within the home, the resident's right to avoid unwanted speech was found to be superior to any and all attempts to communicate with her. ${ }^{200}$

The fair opportunity theory, then, is a way of framing the issue of how courts can balance the rights of free speech and privacy in deciding whether or not to grant a residential picketing injunction. It says that courts can strike this balance based on a demonstrated intent primarily to physically and psychologically

could not complain that they had not received a fair opportunity to communicate to the targeted resident.

197. 438 U.S. 726 (1978).

198. 336 U.S. 77 (1949).

199. Pacifica Found., 438 U.S. at $748-49$ ("To say that one may avoid further offense by turning off the radio when he hears indecent language is like saying that the remedy for an assault is to run away after the first blow."); id. at 759 (Powell, J., concurring in part and concurring in the judgment) ("Although the First Amendment may require unwilling adults to absorb the first blow of offensive but protected speech when they are in public ... a different order of values obtains in the home.") (citations omitted); Kovacs, 336 U.S. at 86-87 (noting that sound truck regulation, unlike those forbidding the distribution of handbills, was permissible because it regulated an intrusion that the resident could not avoid by refusing to accept the proffered communication).

200. In fact, the fair opportunity model is more akin to the regulation upheld in Rowan v. United States Post Office Dep't, 397 U.S. 728 (1970). In Rowan, the Court required mailers who wished to communicate with residents to cease on request of the addressee. Id. at 737. By the same token, the fair opportunity theory also requires an affirmative act of the resident-the seeking of a court-ordered injunction-to invoke the privacy protections. Indeed, in comparison to Rowan, the fair opportunity model for residential picketing injunctions puts a far heavier burden, both motivational and financial, on the homeowner to protect her privacy interests. 
intimidate rather than to coinmunicate. ${ }^{201}$ This intent may be inferred from a number of factors that go to prove that the conduct has become an end in itself rather than a means to the end of expressing an opmion. The fair opportunity theory does not say that the picketers' message is, at some point, no longer valuable in the marketplace of ideas; it suggests only that the conduct of picketing can become so invasive that it can no longer be tolerated despite the value of the message sought to be communicated thereby.

\section{CONCLUSION}

This Note has argued for a new balance between free speech and residential privacy in the residential picketing injunction cases. As the post-Frisby cases demonstrate, the balance struck in Frisby is not working-at least not for residents. In attempting to strike a new balance, courts are justified in granting injunctions barring defendants from picketing within several hundred feet of a particular home because these courts are working with facts that the Supreme Court did not have available to it in Frisby. ${ }^{202}$

These facts show several things. They show that the picketing has created an actual harm to the resident's privacy interest. The existence of this real harm takes the injunctions out of the realn of prior restraimt and puts them within the realm of subsequent punishments for harms already committed. Proof of harm also allows courts to fashion content-neutral regulations on picketing as conduct: it is the picketing itself that creates the harm that courts may enjoin, regardless of the inessage sought to be communicated thereby. Moreover, the evidence in the post-Frisby residential picketing injunction cases proves that focused picketing can consist of more than simply standing in front of a single residence, for the Frisby Court's definition of focused picketing was based on the picketers' intent, not inerely on the physical parameters of the picket line. Under Frisby, focused picketing occurs wherever picketing is primarily intended to invade residential privacy. Once the definition of focused picketing is recognized as being broader than

201. The fact that some intent to communicate is inherent in each instance of picketing is not dispositive; the Frisby Court made clear that "even if some such picketers have a broader communicative purpose, their activity nonetheless inherently and offensively intrudes on residential privacy." Frisby v. Schultz, 487 U.S. 474, 486 (1988).

202. See id. at 488 (noting that Frisby was a facial challenge). 
the particular example offered in Frisby, courts may fashion injunctions barring this type of picketing consistent with the time, place, and manner doctrine. These injunctions may be broader than the ban specifically approved in Frisby and still meet the narrow tailoring and ample alternative channels requirements as long as they seek to do no more than remove that physical presence that is the evil of focused picketing and do not bar picketing in other locations or other forms of communication that have not been shown to invade residential privacy. Finally, the facts of the residential picketing injunction cases reveal the need for some model for determining when the balance that an injunction seeks to establish has been tipped in favor of residential privacy rights. Once picketers have had a fair opportunity to air their legitimate grievances, little justification exists for allowing them to continue to invade residential privacy. When the conduct becomes an end in itself-merely a means of physical and psychological intimidation-it may be enjoined.

To those who remain unconvinced that First Amendment rights must yield to residential privacy interests in these cases, it is important to note that the absence of privacy may actually have a greater chilling effect on freedom of speech than any speech regulation a legislature or court could impose. ${ }^{203}$ Courts have long recognized that to survive, democracy cannot be a free-for-all, that " $[t]$ o enforce freedom of speech in disregard of the rights of others would be harsh and arbitrary in itself." ${ }^{204}$ As Justice Douglas observed,

Liberty . . must mean more than freedom from unlawful governmental restraint; it must include privacy as well, if it is to be a repository of freedom. The right to be let alone is indeed the beginning of all freedom .... When we force people to listen to

203. Ruth Gavison, Too Early for a Requiem, 43 S.C. L. REv. 437, 456 (1992) ("A society without privacy . . . likely will not enjoy much freedom or have robust individuals who are willing to experiment, dare, and challenge their governments and the positive morality of their societies.").

204. Kovacs v. Cooper, 336 U.S. 77, 88 (1949); see also Consolidated Edison v. Public Serv. Comm'n, 447 U.S. 530, 546 (1980) (noting that "some forms of orderly regulation actually promote freedom more than would a state of total anarchy."); Cox v. Louisiana, 379 U.S. 536, 554 (1965) ("The constitutional guarantee of liberty implies the existence of an organized society maintaining public order, without which liberty itself would be lost in the excesses of anarchy."). 
another's ideas, we give the propagandist a powerful weapon .... Once privacy is invaded, privacy is gone. ${ }^{205}$

Without opportunities for quiet reflection and private self-examination, people cannot be expected to formulate informed opinions or to adopt coherent positions from the vast array of opinions competing for their allegiance.

Those who would champion free speech rights therefore cannot automatically be assumed to prevail over those who seek to protect other important freedoms. To do so threatens not only other significant interests but free speech itself. Free speech is without question an important and precious right, the cornerstone of a free society. Yet no right exists to wrap oneself in the First Amendment and "use it as an iron standard to smooth [one's] path by crushing the living rights of others to privacy and repose. ${ }^{206}$ In the exercise of First Amendment freedoins, might does not necessarily inake right. ${ }^{207}$ Freedom includes both the right to speak one's mind and the right to make up one's mind free from physical and psychological intimidation, and both of these values are equally iinportant aspects of true liberty. ${ }^{208}$

205. Public Utils. Comm'n v. Pollak, 343 U.S. 451, 467, 469 (1952) (Douglas, J., dissenting).

206. Breard v. Alexandria, 341 U.S. 622, 626 (1951).

207. See Gregory v. City of Chicago, 394 U.S. 111, 124 (1969) (Black, J., concurring) (stating that to deny government the power to regulate conduct such as picketing "would subject all the people of the Nation to the uncontrollable whim and arrogance of spcakers, and writers, and protesters, and grievance bearers"). The marketplace of ideas would be greatly impoverished if it were to operate solcly on the squeaky whcel principle.

If subjecting one's faunily and neighbors to the harassment of demonstrations and picketing is the price a private citizen must pay for expressing his views then surely we will lose the one pervading thought which our founding fathers have conveyed to us - that of fostering the free and open exchange of ideas. A silent majority is enough. We should not become a country where only the most boisterous voices are hcard.

Walinsky v. Kennedy, 404 N.Y.S.2d 491, 498 (Sup. Ct. 1977).

208. See Kovacs, 336 U.S. at 86 ("The right to speak one's mind would often be an empty privilege in a place and at a time beyond the protecting hand of the guardians of public order."). In fact, the two values are inextricably intertwined.

[F]reedom of expression is so important because of its relationship to the kind of individuals that we want to have and the kind of society in which we want to live. In order to have that very society, we need more than freedoun of speech. We need other forms of freedoms, virtues, and aspirations. Privacy is not inerely another important value that occasionally conflicts with free expression. Privacy is essential, in different ways, to the very same goals that we seek to pursue through freedom of expression.

Gavison, supra note 203 , at 460 (footnote omitted). 